\title{
Catarismo, uma manifestação utópica medieval
}

\author{
Hilário Franco Júnior ${ }^{1 *}$
}

\section{RESUMO}

Embora a atual tendência historiográfica seja negar o estatuto de utopia a todo movimento social e toda criação literária ou artística anteriores à obra de Thomas More (1516), o presente trabalho defende sua pertinência em relação à Idade Média e propôe exemplificar com um fenômeno sociorreligioso dos séculos XII-XIV, a heresia cátara.

Palavras-chave: Idade Média; utopia; heresia; catarismo.

\section{Catharism, a Medieval Utopian Manifestation}

\section{ABSTRACT}

Although the current historiographic trend is to deny the status of utopia to every social movement and to all literary or artistic creation prior to the work of Thomas More (1516), the present work defends its pertinence in relation to the Middle Ages, and proposes to exemplify it with a socioreligious phenomenon of the period between the 12th and 14th Centuries, the Cathar heresy.

Keywords: Middle Ages; utopia; heresy; Catharism.

\section{Catarismo, una manifestación utópica medieval}

\section{RESUMEN}

Aunque la actual tendencia historiográfica niegue el estatuto de utopía a todo movimiento social y toda creación literaria o artística anterior a la obra de Tomás Moro (1516), el presente trabajo defiende su permanencia en relación a la Edad Media y propone, al mismo tiempo, ejemplificar con un fenómeno sociorreligioso de los siglos XII-XIV, la herejía cátara.

Palabras clave: Edad Media; utopía; herejía; catarismo.

DOI: http://dx.doi.org/10.1590/2237-101X01903801

Artigo recebido em 16 de dezembro de 2017 e aprovado para a publicação em 10 de janeiro de 2018.

${ }^{1}$ Universidade de São Paulo, São Paulo, São Paulo, Brasil.

* Professor aposentado do Departamento de História da USP. E-mail: cliofrancojr@hotmail.com. 


\section{O problema conceitual}

O título do presente trabalho pode parecer a alguns conter uma dupla impertinência conceitual: falar em utopia a propósito da Idade Média e considerar a heresia cátara como forma utópica. É fato que por longo tempo, e em certa medida até hoje, a medievalística rejeitou aplicar o conceito de utopia ao período medieval, argumentando que a palavra foi forjada por Thomas More em fins de 1516 e concluindo disso que antes dele não poderia ter existido utopias. Mesmo porque, acrescentam os adeptos dessa linha interpretativa, a Europa medieval projetava no Além seus sonhos de perfeição, possível somente na Cidade de Deus, não na Cidade dos Homens, de maneira que o cristianismo se revela incompatível com a utopia.

A outra objeção poderia vir da corrente atual de estudos das heresias, que, paradoxalmente, pôe em causa a própria existência delas, argumentando que foram uma "invenção" dos poderes eclesiásticos e monárquicos para se reforçar graças à figura de Outro taxado de perigoso e demoníaco. No contexto da Reforma dita gregoriana, criminalizar toda forma de dissidência tornou-se estratégia eclesiológica e política. Não foi casual que muitos polemistas anti-hereges em geral, inclusive anticátaros, tenham desempenhado importante papel institucional como inquisidores, caso de Moneta de Cremona ( $† 1238)$ ou de Raniero Sacconi (†1262). O rótulo de heresia recobre, portanto, segundo essa linha interpretativa, mais os interesses do projeto teocrático e centralista da Igreja do que uma realidade doutrinária, o que impede, afirmam esses historiadores, de atribuir a grupos diferentes uma identidade única sob o rótulo geral de "catarismo".

Frente a esses argumentos, é preciso lembrar, de um lado, que qualquer realismo (no sentido filosófico medieval, isto é, de conceitos que antecedem as coisas) excessivo esvaziaria o vocabulário historiográfico: feudalismo ou Cruzada, por exemplo, são palavras posteriores aos fenômenos que designam. Também em relaçáo a "utopia", mais importante do que a palavra é a coisa, dado antropológico, não apenas histórico ${ }^{2}$ - uma sociedade terrena ideal, com justiça social, não é exclusividade de uma época ou de uma região, mas de grupos humanos de horizontes variados. Foi o caso entre os gregos antigos da República de Platão e das ilhas Afortunadas; entre os celtas da Terra da Juventude e da ilha de Avalon; entre os ameríndios do Eldorado e da Terra Sem Mal. Não importa a existência de uma literatura utópica definida por cânones posteriores, o essencial é o espírito utópico, que a partir de More tão somente recebeu um nome particular.

De outro lado, se à primeira vista o cristianismo parece negar o princípio utópico por visar o Reino de Deus, "que não é desse mundo", ${ }^{3}$ isso nunca impediu os medievais de se envolverem

\footnotetext{
${ }^{2}$ QUARTA, Cosimo. Livelli del pensiero utopico: antropologia, storia, letteratura. Morus, Campinas, v. 6, p. 232-239, 2009.

${ }^{3}$ João XVIII, 36.
} 
na procura física, material, do Paraíso terrestre, que distinguiam mal do Paraíso celeste. Ou seja, um projeto utópico para este mundo era possível, daí o jesuíta holandês Frans Van Bladel reconhecer que "o cristianismo é uma utopia”. ${ }^{4}$ A prova está no fato de a Europa medieval cristã não ter deixado de aceitar a existência de sociedades terrenas quase perfeitas, embora efêmeras, justamente porque o fim último estaria no Além. Foi o caso, no cristianismo eclesiástico, do monasticismo e da peregrinação, ${ }^{5}$ ou, flertando com a heresia, do franciscanismo e da Florença de Savonarola. O cristianismo laico reconhecia sociedades perfeitas com maior desenvoltura: são exemplos disso o país de Cocanha, o império de Preste João, o reino do Graal, a comunidade de Robin Hood, o milenarismo, ou a terra de Santo Amaro.

Quanto a "cátaro" ocorreu o inverso, a palavra era antiga e passou, em fins de 1163, a designar uma nova realidade: o abade Egberto de Schönau latinizou em catharos o grego, $\kappa \alpha \theta \alpha \rho o ́ \varsigma$, "puro", que Eusébio de Cesareia usara 840 anos antes para qualificar os hereges novacianos. ${ }^{6}$ Porque tal qualificação era externa aos hereges então identificados em Colônia é que se pôde dizer que "cátaros" foi invenção eclesiástica, e, portanto, se eles não existiram, não poderia ter existido o "catarismo", ainda por cima porque aquilo que a historiografia do século XIX assim chamava não era homogêneo do ponto de vista doutrinal. E, poderíamos acrescentar, nem do ponto de vista documental, já que as fontes internas que hoje possuímos, produzidas pelos próprios cátaros, limitam-se a três textos rituais e dois tratados, todo o corpus restante sendo de procedência católica. Tampouco havia homogeneidade do ponto de vista sociológico, mesmo se a adesão àquela heresia parece ter sido mais urbana que rural, mais de segmentos sociais abastados do que pobres.

Contudo, se "inventar a heresia" é afirmativa verdadeira em relação ao nome, não o é em relação à coisa: esta, independentemente do rótulo que se lhe aplicasse, tinha concretude social e religiosa. Não se pode nessa matéria falar em "inventar" no sentido de "criar", o que seria claramente um exagero, e sim na acepção etimológica de "descobrir". De todo modo, é preciso reconhecer que não se deve estudar aquela heresia de maneira global, e sim nas suas manifestaçôes locais: o Languedoc, a região em torno de Lyon, a Lombardia, a área Verona-Vicenza, a Toscana, subsidiariamente a Renânia, a Inglaterra, o sul italiano, Aragão, León. De fato, é mais exato falar em catarismos, no plural. ${ }^{7}$ Mas sem que isso signifique

\footnotetext{
${ }^{4}$ Penser l'utopie. Collectanea Cisterciensia. Revue de spiritualité monastique, Orval (Bélgica), v. 65, p. 48, 2003. ${ }^{5}$ FRANCO JÚNIOR, Hilário. A utopia que não está no fim da viagem: a peregrinaçấo. Morus, v. 7, p. 155-177, 2010; Nos confins do mundo, na vizinhança do Paraíso: a utopia monástica. Graphos, João Pessoa, v. 19, n. 3 , 2017, p. 9-32. Disponível em: <http://periodicos.ufpb.br/ojs2/index.php/graphos/article/view/37771/19074>.

${ }^{6}$ EGBERTO DE SCHÖNAU. Sermones contra catharos. In: MIGNE, Jacques-Paul (Ed.) Patrologia Cursus Completus. Series Latina. [1844-1864]. Turnhout: Brepols, 1855. v. 195, I, 5, col. 17d-18a; V, 6, col. 31a; EUSÉBIO DE CESAREIA. Histoire ecclésiastique. Edição e tradução de Gustave Bardy. Paris: Cerf, 1955. (Sources Chrétiennes, v. 41), VI, 43, 1, p. 153. A palavra também foi usada em relação àqueles hereges por EPIFÂNIO DE

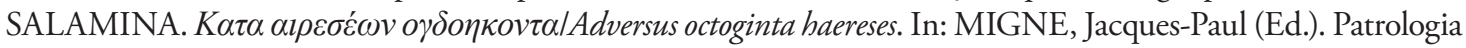
Cursus Completus. Series Graeca. Turnhout: Brepols, 1984-1991. v. 41, II, 39 (59), col. 1017-1038.

7 JIMÉNEZ-SANCHEZ, Pilar. Les catharismes. Modèles dissidents du christianisme médiéval (XII ${ }^{e}$-XIII ${ }^{\mathrm{e}}$ siècles). Rennes: Presses Universitaires de Rennes, 2008.
} 
desconsiderar o fato de que ao longo de três séculos alguns milhares de pessoas ("cátaras" na linguagem da Igreja e da historiografia) viveram pautadas por um mesmo conjunto básico de crenças, apesar de variantes locais. Dessas crenças derivaram comportamentos e ideais comuns aos seus vários grupos, o que incluía especulações de caráter utópico. É esse denominador comum que nos interessa aqui e que justifica falarmos em catarismo, no singular.

\section{Toda heresia é utópica, toda utopia é herética}

Tinha razão o filósofo húngaro Thomas Molnar quando propôs, há 50 anos, que a utopia está para a política assim como a heresia para a teologia. Seu argumento é que o pensamento utópico é de natureza religiosa - todo utopista tem sua principal motivação na pureza absoluta, ele julga intolerável a existência do mal (do qual não está, porém, isento, paradoxalmente aceitando-o em um primeiro momento em nome de sua posterior e definitiva extirpaçáo). $\mathrm{O}$ utopista, ao atacar os fundamentos do estado humano, quer a reconstrução total, exige que Deus e a Criaçáo sejam repensados. Ao pretender libertar o homem da providência divina em nome da autonomia de uma coletividade, ele usurpa as prerrogativas e os atributos de Deus, torna-se herege, pois a identificação implícita de Deus com a sociedade utópica resulta em uma forma de religiáo secularizada, panteísta. Todo utopista, ao fazer uma escolha diferente para sua sociedade, é herege em relaçáo ao statu quo, todo herege, ao ir contra o entendimento e a vivência oficiais da religião e da sociedade, propondo outra interpretação, é utopista. ${ }^{8}$

Para testarmos a hipótese geral de as heresias medievais terem sido expressóes utópicas, devemos verificar nelas, ainda que rapidamente, a presença dos três elementos constituintes de toda utopia - ideologia, mitologia, rito. O primeiro, que no senso comum quase se confunde com ela, é construçáo intelectual que avalia a realidade vivida, ou justificando-a (quando sua própria imagem da sociedade é hegemônica) ou criticando-a (quando busca ser hegemônica). A partir dessa interpretação parcial (no duplo sentido de parte de um todo e de não neutralidade) da realidade imediata, ela formula uma visão global e histórica da sociedade que, sem reconhecê-lo, comporta forte carga utópica. É isso que revela a etimologia de "heresia". No grego arcaico, como em Heródoto, e no clássico, caso de Tucídides, $\alpha i ́ p \varepsilon \sigma l \varsigma$, airesis, indicava literalmente o ato de "tomar posse" e, figurativamente, uma escolha, boa ou má. Essa foi a acepção usada pela tradução bíblica dos Setenta (séculos III e II a.C.) e, no mundo latino, aceita por Tertuliano no século II ou Roberto Grosseteste no XIII. ${ }^{9}$ Depois, a palavra passou a designar escola ou seita (mas sem cono-

\footnotetext{
${ }^{8}$ MOLNAR, Thomas. Utopia, the perennial heresy. Nova York: Sheed and Ward, 1967.

9 TERTULIANO. De praescriptione haereticorum. Edição de François Refoulé et alii. Corpus Christianorum Series Latina. Turnhout: Brepols, 1954. v. 1, VI, 2, p. 191, linhas 7-8 ("haereses dictae graeca uoce ex interpretatione electionis”); GROSSETESTE, apud MATEUS PARIS. Chronica majora, anno 1253. Edição de Henry R. Luard. Londres: Longman, 1876, p. 401 (“haeresis graece, electio latine”).
} 
tação pejorativa), como a empregou o judeu helenizado Flávio Josefo por volta de 75 ao se referir a saduceus, fariseus e essênios.

O sentido depreciativo tornar-se-ia predominante a seguir, abonado no fim do século I por um texto bíblico, e no II por Tertuliano e Ireneu. Para este, heresia é falsificar a palavra de Deus, é à doutrina do Evangelho preferir uma visão pessoal; para aquele, é "arbítrio de inovar sua fé". Concordam que é arbítrio nas coisas da Igreja, tanto Cipriano no século III como Isidoro de Sevilha no VII. ${ }^{10}$ Mostrando como a rotulação negativa de "heresia" tinhase imposto e eliminado a acepção neutra, entre 1013 e 1020 o hagiógrafo de Santa Foy qualificou de "herege" um camponês que não acreditava nos milagres intermediados pela santa, vendo nele "um filho do Diabo", um "servidor do Anticristo"."

Náo havia uma fronteira natural entre ortodoxia e heresia, apenas um choque de jurisdição sobre as ideias cristãs, que a primeira procurava monopolizar e a segunda, liberalizar. Uma pretendia deter o único e verdadeiro entendimento da palavra divina, a outra defendia a liberdade de interpretação. Ao corporativismo pretensamente iluminado dos bispos, Santo Ambrósio opôs o individualismo desregrado dos hereges, cuja impertinência no entendimento do cristianismo tornou-os "adversários da fé, inimigos da verdade". ${ }^{12}$ Eles passaram a representar o maior perigo à unidade da Igreja nascente e depois às pretensóes unitaristas e universalistas da Igreja gregoriana. Contra esta é que uma lista italiana de crenças cátaras conhecida por Herrores heretiquorum (meados do século XIII) assevera, por exemplo, que "os sacerdotes não devem dominar o povo", "nenhuma pessoa má pode ser bispo" ou "a Igreja não pode excomungar". ${ }^{13}$

O segundo elemento a levar em conta é que a força da ideologia não decorre apenas da suposta justiça do projeto utópico, mas também — ou sobretudo, nos casos históricos mais recuados - de uma mitologia que está na base da proposta utópica. Se, como pensa Freda Dröes, o catarismo chegou ao limite da cultura da época, colocando-a em xeque, não foi apenas por ideologia diversa, mas também por sua mitologia, mostraram outros autores. ${ }^{14}$ Como

\footnotetext{
${ }^{10}$ Epístola a Tito III, 10; IRENEU. Contra as heresias. In: Doutreleau, Louis; Rousseau, Adelin (Ed./Trad.). Contre les hérésies. Paris: Cerf, 1979. (Sources Chrétiennes, v. 264), I, prefácio, 1, p. 19; TERTULIANO. De praescriptione haereticorum, op. cit., XLII, 8, p. 222, linha 19; CIPRIANO. Liber de unitate ecclesiae. In: MIGNE, Jacques-Paul (Ed.). Patrologia Cursus Completus. Series Latina. [1844-1864]. Turnhout: Brepols, 1844. v. 4, 10, col. 507b; ISIDORO DE SEVILHA. Etimologías, VIII, 3, 2. Edição de Wallace M. Lindsay. Tradução de José Oroz Reta e Marco Casquero. Madri: BAC, 1982, p. 690. v. I.

${ }^{11}$ Liber miraculorum Sancte Fidis, I, 7, 12-21. Edição de Luca Robertini. Spoleto: Cissam; Florença: Sismel, 1994, p. 99.

12 AMBRÓSIO, Santo. Expositio Psalmi CXVIII. Tradução de Luigi Franco Pizzolato. In: Petschenig, Michael (Ed.). Commento al Salmo CXVIII. Milão/Roma: Biblioteca Ambrosiana/Città Nuova, 1987, p. 62-62. (Operaomnia di Sant'Ambrogio, v. 10).

${ }^{13}$ Herrores heretiquorum. In: Molinier, Charles (Ed.). Un texte de Muratori concernant les sectes cathares: sa provenance réelle et sa valeur. Annales du Midi, Toulouse, v. 22, p. 215 ("sacerdotes non debent regere populum", "nullus malus potest esse episcopus", "Ecclesia non potest excommunicare"), 1910.

${ }_{14}$ DRÖES, Freda. De Katharen grens van een cultuur? Amsterdã: Katholieke Theologische Hogeschool, 1982; GRECO, Alessandra. Mitologia catara. Il favoloso mondo delle origini. Spoleto: Cissam, 2000 p. 224;
} 
todo presente se faz com certa visão do passado (mítico ou miticizado) e determinada expectativa do futuro (ideologizado), as utopias são uma forma de preenchimento desse espaço histórico. Se a faceta ideológica da utopia pode, em variada medida, ser autoral, pessoal, a faceta mitológica é fornecida pelo capital mítico da sociedade em que se elabora o projeto utópico. Enquanto o objetivo utópico é justificado racionalmente pela ideologia, é expressado literariamente por meio de mitos. Se havia certa falta de expectativa utópica no cristianismo oficial, como defendem alguns historiadores, as heresias não seriam justamente uma resposta a isso?

O choque ideológico náo poderia ficar ausente de um campo cultural táo importante na formação do cristianismo como a mitologia. Desde os primeiros tempos, a nova religiáo insistiu sobre a oposição entre a verdade evangélica e as falsidades mitológicas, prolongando em outro registro a já entáo antiga oposiçáo entre Logos e Mythos. Náo por acaso, aliás, o autor do prólogo do evangelho de João, talvez um grego de fins do século I, refere-se a Cristo como sendo o Logos de Deus, terminologia adotada pela patrística grega. Essa opçáo fazia parte do processo de desmitologização do cristianismo, iniciada pelo mais grego dos autores bíblicos, São Paulo. Em razão dessa herança antimítica, o cristianismo oficial, desde seus primeiros tempos, e ao longo de toda a Idade Média, várias vezes denunciou a presença mitológica nas heresias, sem perceber (por razóes ideológicas) que ele próprio é uma mitologia. Mesmo parte da erudição moderna não pôde se desvencilhar dessa herança cristã e tendeu a minimizar o papel do mito. Um grande especialista como Raoul Manselli pensava que, embora "elemento fundamental da fé", o mito não funcionou no catarismo como "consciência libertadora", a não ser de maneira "complementar e relativa". Mas, nesse caso, não teria sentido aquilo que os polemistas católicos medievais chamavam de secretum cátaro, ou seja, sua mitologia revelada aos crentes apenas depois de 15 anos de adesão à seita. ${ }^{15}$

Náo se pode negar que a mitologia cumpriu papel essencial na visão de mundo das heresias em geral. Nesse campo deu-se muito do choque entre as duas vertentes religiosas, e em especial entre catolicismo e catarismo, cujas mitologias eram bastante divergentes. Por exemplo, o texto conhecido como Interrogatio Iohannis, tradução latina de fins do século XII de um texto búlgaro (por sua vez de provável origem bizantina), dentre outras coisas explica que Satanás separou a água da terra, criou os astros, os animais, os peixes, as aves, a vegetação, modelou o corpo humano e fez aí entrar um anjo caído, fornicou sob forma de serpente com a mulher. ${ }^{16}$ De acordo com algumas fontes, os cátaros viam em Satanás o irmão de Cristo, de acordo com outras, o irmão de Adão. ${ }^{17}$

FRANCO JÚNIOR, Hilário. Catolicismo e catarismo, um choque de mitologias. Cadernos de História, Belo Horizonte, v. 12, p. 9-28, 2010.

${ }^{15}$ MANSELLI, Raoul. Église et théologies cathares. In: Cathares en Languedoc. Toulouse: Privat, 1968 (Cahiers de Fanjeaux, 3), p. 154; EGBERTO. Sermones contra catharos, op. cit., II, 2, col. 19cd.

${ }^{16}$ Le livre secret des cathares. Interrogatio Iohannis, apocryphe d'origine bogomile. Edição e tradução de Edina Bozóki. Paris: Beauchesne, 1980, p. 56-61.

${ }^{17}$ Respectivamente, PEDRO DES VAUX-DE-CERNAY. Hystoria Albigensis, I, 12. Edição de Pascal Guébin e Ernest Lyon. Paris: Honoré Champion, 1926, p. 12; PREPOSTINO DE CREMONA. Svmma contra 
Por fim, o terceiro elemento, que condensa e materializa os anteriores, é o rito. Ou seja, ação gestual e verbal codificada que periodicamente reúne todos os membros do grupo, cimenta os elos entre eles teatralizando a perfeição daquela comunidade, ao relembrar explícita ou implicitamente seus mitos fundadores. É assim tanto na missa católica como na refeição comunitária na Utopia ou no atual cerimonial político chinês. Algumas vezes o rito antecede a formulação ideológica, funcionando como uma espécie de ação propiciatória para ela. Outras vezes ocorre depois, funcionando como ação ao mesmo tempo mnemônica e legitimadora daquela formulaçáo. Se a liturgia ("serviço para o bem público") funciona como denominador comum da sociedade, estar excluído dela é ser marginalizado: embora na ilha da Utopia as pessoas possam comer em casa, isso não é comum, já que evitar as refeiçôes comunitárias "é algo muito mal visto". 18

Da ideologia e da mitologia dissidentes dos heréticos decorreu sua liturgia particular, em todos os grupos bem menos extensa que a católica. No caso dos cátaros, refutou-se a existência de uma Falta inicial ("originale peccatum non est") procedente não de escolha humana ("pecatum non est a libero arbitrio"), por ver no Mal anjos caídos aprisionados em corpos humanos ("nullum bonum est in carne"), o que levou à rejeição automática da Encarnaçáo ("Xristus non fuit verus homo") e, portanto, da Igreja que se construíra em torno daquele evento ("sacramentum altaris nibil est")..$^{19}$ A partir de 1250, para indicar que sua comunidade constituia a única Igreja legítima, os cátaros chamam-na de gleisa de Dio (ecclesia Dei nos relatos católicos), oposta à Igreja católica (gleisa malignant, ecclesiae malignantium, Ecclesiam diaboli). Enfim, o grau de desvio da mitologia e da ideologia cátaras em relação à mitologia e à ideologia católicas é que definiu seu perfil litúrgico.

Apesar das diferenças regionais entre os catarismos, havia, do ponto de vista litúrgico, dois elementos comuns. Um, a prece, limitava-se praticamente ao Pater Noster, que devia ser recitado várias vezes ao dia. Outro, existia um único sacramento, a imposição das mãos (consolament em occitano, consolamentum em latim), ao mesmo tempo rito de ordenaçáo para a elite espiritual da comunidade e extrema-unção para os crentes moribundos. É fato que uma vez por mês recorria-se ao aparelhament ("preparação"), confissão feita individualmente, em público, com absolvição coletiva,$^{20}$ mas sem caráter sacramental. Não contando na sua mitologia, como vimos, com a ideia do Pecado original (que pressupóe o livre-arbítrio, inexistente em criaturas do Diabo), os cátaros não aceitavam o batismo (que reintroduz a

haereticos, I. Ediçẫo de Joseph Garvin e James Corbett. Notre Dame (Indiana): University of Notre Dame Press, 1958. p. 4-6.

${ }^{18}$ MORE, Thomas. L'Utopie. Reprodução fac-símile. Edição e tradução de André Prévost. Paris: Mame, 1978, p. 157-159. II.

${ }^{19}$ As citações são de: Herrores heretiquorum, op. cit., as duas primeiras (p. 215) e as duas últimas (p. 214 e 215); PREPOSTINO DE CREMONA. Svmma contra haereticos, op. cit., I, 13, p. 19, linhas 452-453, a terceira. ${ }^{20}$ SACCONI, Raniero. Summa de catharis et leonistis pauperibus de Lugduno. Edição de François Sanjek. Archivum Fratrum Praedicatorum, Roma, v. 44, p. 46, linhas 1-2, 1974; ANSELMO DE ALEXANDRIA. Tractatus de hereticis. In: Dondaine, Antoine (Ed.). La hiérarchie cathare en Italie. Archivum Fratrum Praedicatorum, Roma, v. 20, p. 315, linhas 18-20, 1950. 
esperança de salvação, fato negado por eles). Para eles os sacramentos da Igreja são deceptoria et diabolica, expressão (ideológica) próxima à que um autor dominicano utiliza (ideologicamente) para se referir à penitência praticada pelos hereges, deceptoria et uenenosa. ${ }^{21}$

\section{A heresia-utopia cátara}

Admitido, então, o caráter utópico das heresias, quais eram esses traços no caso particular do catarismo? O primeiro deles é revelado até mesmo pelo nome que lhe foi atribuído pelas fontes católicas: catharos, "puro", sendo os membros da elite espiritual do grupo qualificados de perfecti, isto é, "hereges perfeitos". Apesar de esses termos serem irônicos na pena dos autores católicos, o sentido era semelhante na nomenclatura interna à comunidade herética do Sul francês, a zona mais ampla e de presença mais duradoura da heresia: desde 1165, para marcar sua diferença com a Igreja da época os ministros cátaros autodenominam-se veri christiani ou bonos cristianos. ${ }^{22} \mathrm{Ou}$ ainda bos homes, bos crestias ou crestias, em occitano. Os demais membros da comunidade são simplesmente crentes (crezents ou credentes). Ou, vistos de fora, a partir de 1209 são "albigenses", uso metonímico da denominaçáo dos habitantes de um dos polos do grande triângulo herético, Albi-Carcassone-Toulouse.

Embora a terminologia oficial pretendesse ser depreciativa, náo deixava de manifestar a acentuada pureza dos Perfeitos, pureza táo flagrante que algumas vezes foi reconhecida mesmo por contemporâneos católicos. É o caso, do começo do século XIII, de um cavaleiro da região de Ariège (sudoeste francês) considerado "sábio" pelo cronista que narra o episódio, e que explica ao bispo de Toulouse que não poderia perseguir os cátaros por conhecer o "honeste vivere" deles. Ou ainda, do último ano do mesmo século, caso de um católico de Albi que admite a vida santa dos hereges devido à sua prática de castidade, penitência e abstinência. ${ }^{23}$

Essa pureza era a consequência comportamental inevitável da metafísica cátara, que concebia a existência de duas divindades: uma boa, criadora dos anjos e dos espíritos; outra má, criadora de toda matéria, inclusive dos humanos. Daí por que a Igreja dos cátaros não é de pedra nem de madeira ou qualquer outra matéria ("non es de peiras ni de fusta ni

\footnotetext{
${ }^{21}$ SACCONI, Raniero. Summa de catharis et leonistis pauperibus de Lugduno, op. cit., p. 42, linha 22; p. 43, linha 1; p. 44, linha 18.

${ }^{22}$ Por exemplo, no Rituel cathare, THOUZELLIER, Christine Thouzellier (Ed./Trad.) Paris: Cerf, 1977. (Sources Crétienes, v. 236), 10, p. 236, linha 10; 12, p. 246, linha 27; 13, p. 246, linhas 6-7; 14, p. 260, linha 55; Livre des deux principes. In: Thouzellier, Christine. Livre des deux principes. Paris: Cerf, 1973. (Sources Crétienes, v. 198), 45, p. 318, linha 70; 66, p. 410, linha 14; 69, p. 432, linha 9.

${ }^{23} \mathrm{O}$ primeiro testemunho é de GUILHERME DE PUYLAURENS. Chronica/Chronique, 1145-1275, VIII. Tradução e edição de Jean Duvernoy. Toulouse: Le Pérégrinateur, 1996, p. 56. O segundo de um interrogatório inquisitorial realizado pelo bispo de Albi nos dois últimos anos do século XIII e citado por DOUAIS, Mari-Jean Célestin. Les manuscrits du château de Merville. Annales du Midi, v. 2, n. 6, p. 182183, 1890: "vivebant bene et sancte" (fol. 34); "tenebant magnam castitatem et faciebant magnam penitentiam (fol. 69); "erant magne sanctitatis et magne abstinentie" (fol. 74).
} 
de nenguna cosa faita de man"), diz o Ritual de Dublin. ${ }^{24}$ Se para pequenos grupos o culto ocorria na residência de um crente, no caso de mais gente a reunião era em celeiros, oficinas de tecelagem ou porôes. Locais específicos para o culto inexistiam - "Deus está tanto numa casa quanto na igreja", declarou um herege ao interrogatório inquisitorial dirigido pelo cisterciense Jacques Fournier, bispo de Pamiers (sudoeste francês) e futuro papa Bento XII. ${ }^{25}$ As implicações do dualismo eram ainda mais amplas, e não eximiam o ser humano delas: em fins do século XII um teólogo católico, futuro chanceler da Universidade de Paris, Prepostino de Cremona, explicou que para os hereges a natureza espiritual é completamente boa e a carnal, completamente má ("natura spiritus est tota bona, ergo natura carnis est tota mala"), concluindo que "diabolus creavit corpus". ${ }^{26}$

Detalhando a ideia, os hereges garantiam que tinha sido Satanás quem ensinou aos humanos como reproduzir seus corpos. Sob forma de serpente, com a cauda ele fornicou com Eva, gerando Caim e mostrando como pecar, o que ela faria a seguir com Adão para conceber Abel. ${ }^{27}$ Logo, em vez da otimista visão católica de o homem "feito à imagem e semelhança de Deus", os cátaros concebiam-no como mero receptáculo criado pelo Deus do Mal para aprisionar os anjos cuja Queda ele provocara. Porque o corpo humano é opus satanicum, um cátaro interrogado pela Inquisição em 1320 pôde afirmar que "os diabos são nossos irmãos". ${ }^{28} \mathrm{Em}$ contradiscurso ao mesmo tempo ideológico e mitológico, a Igreja católica (aliás redirecionando as acusaçôes que os pagãos haviam feito à primitiva comunidade cristâ) atribuiu aos cátaros (e outros hereges) práticas sexuais desregradas, libertinas, sodomíticas, incestuosas.

$\mathrm{Na}$ verdade, o casamento era aceito para os crentes apenas como concessáo à fraqueza humana. A condição de perfectus implicava rejeição total e definitiva a qualquer prática sexual devido ao perigo que ela significa para a alma. Um texto de fins do século XII afirma que "ninguém pode se salvar no casamento exercendo a atividade conjugal" ("neminem in coniugio posse

${ }^{24}$ Un recueil cathare: le manuscrit A.6.10 de la Collection vaudoise de Dublin, I. VENCKELEER, Théo (Ed.). Revue belge de philologie et d'histoire, Bruxelas, v. 38, p. 820, linhas 3-4, 1960.

${ }^{25}$ Registre, v. III, p. 15.

${ }^{26}$ PREPOSTINO DE CREMONA. Svmma contra haereticos, op. cit., I, 14, p. 20, linha 484; I, 7, p. 10, linhas 220-221 (cf. ainda II, 3, p. 50, linhas 129-130). Várias outras fontes dizem a mesma coisa, caso de ERMENGALDO DE BÉZIERS. Opusculum contra haereticos. In: MIGNE, Jacques-Paul (Ed.). Patrologia Cursus Completus. Series Latina. [1844-1864]. Turnhout: Brepols, 1985-1995. v. 204, 1, col. 1235a; RALPH DE COGGESHALL. Chronicon anglicanum. Edição de Joseph Stevenson. Londres: Longman, 1875, p. 125. ${ }^{27}$ Le livre secret des cathares, p. 60, ms. V, linhas 104-106, ms. D, linhas 95-98; BONACURSO DE MILÃO. Manifestatio heresis catharorum. In: MIGNE, Jacques-Paul (Ed.) Patrologia Cursus Completus. Series Latina. [1844-1864]. Turnhout: Brepols, 1855. v. 204, col. 775b-776a; SALVO BURCI. Liber supra stella. Edição de Ilarino da Milano. Aevum, Milão, v. 19, p. 314, 1945; MONETA DE CREMONA. Adversus catharos et valdenses, II, I, 2. Edição de Tommaso Agostino Ricchini. Roma: N. e M. Palearini, 1743, p. 111; GREGÓRIO DE FANO. Disputatio inter catholicum et paterinum hereticum. Edição de Ilarino da Milano. Aevum, Miláo, v. 14, p. 132, 1940. A filiação diabólica de Caim vinha de antigo mito hebraico registrado por Los capitulos de Rabbi Eliezer, XXI, 1. Edição de David Luria. Tradução de Miguel Pérez Fernández. Valência: Institución San Jerónimo para la investigación bíblica, 1984, p. 162.

${ }^{28}$ Registre, v. II, p. 200, cf. Le livre secret des cathares, p. 60, ms. V, linha 107, ms. D, linha 98. 
salvari exercendo opera coniugalia").29 Outro, de 1147, diz que eles "chamavam todo casamento de fornicaçáa" ("omne conjugium vocant fornicationem"). Outro ainda, datado de 1218, garante que para os cátaros "matrimonium est meretricium". Em meados do século XIII a já citada lista italiana de erros heréticos declara que "matrimonium malum est". Um tratado de 1250 sobre o catarismo atesta que para ele "o matrimônio carnal sempre foi pecado mortal" ("matrimoniam carnale fuit semper mortale peccatum”). Uma deposição feita à Inquisição, em 1323, proclama que "quando se une carnalmente se peca de forma mortal" ("quando se carnaliter coniungebant mortaliter peccabant”). Daí por que, explica um herege, quando a Igreja católica pretensamente legitima o sexo por meio do casamento, ela pratica lenocínio. ${ }^{30}$

Embora administrado uma única vez, o consolament podia ser renovado caso o indivíduo consolado ou o oficiante ou os demais "bons homens" presentes viessem a cometer pecado grave, ingestão de comida de origem animal, homicídio, adultério, fornicação, furto, falso testemunho, perjúrio. ${ }^{31} \mathrm{Ou}$ seja, enquanto no catolicismo é a condiçấo sacerdotal (pouco importando a qualidade moral do indivíduo) que serve de veículo para a transmissão do Espírito Santo, no catarismo é a pessoa do oficiante, da qual se exige, portanto, pureza total. Aqueles que não se sentiam capazes de seguir a moralidade rigorosa dos "bons homens", preferindo se manter como simples crentes ao longo da vida, recebiam o consolament apenas no leito de morte para ter um "bom fim", ou seja, o perdão dos pecados e a reunião da alma com o espírito que encerraria o ciclo de transmigraçóes, ou ao menos proporcionaria progresso na reencarnaçáo seguinte.

O consolament significava a rejeição não só da atividade sexual, como também de toda alimentação de origem animal, embora nem a vegetação tivesse sido criação do Deus bom. ${ }^{32}$ Por isso, mesmo os simples crentes deviam rezar antes de ingerir comida e bebida. Por isso,

\footnotetext{
${ }^{29}$ PREPOSTINO DE CREMONA, Svmma contra haereticos, op. cit., IV, p. 66, linhas 1-2.

${ }^{30}$ Respectivamente, EVERVINO DE STEINFELD. Epistola ad S. Bernardum. In: MIGNE, Jacques-Paul (Ed). Patrologia Cursus Completus. Series Latina [1844-1864]. Turnhout: Brepols, 1985-1995. v. 182, 472, 4, col. 679a; PEDRO DES VAUX-DE-CERNAY. Hystoria Albigensis, op. cit., I, 12, p. 13; Herrores heretiquorum, op. cit., p. 216; SACCONI, Raniero. Summa de catharis et leonistis pauperibus de Lugduno, op. cit., p. 43, linhas 3-4; Registre, v. II, p. 500; Ibidem, v. I, p. 283. A questâo era táo importante do ponto de vista católico que ANDRÉ FLORENTINO, Summa contra hereticos. In: ROTTENWÖHRER, Gerhard (Ed.). Monumenta Germaniae Historica. Quellen zur Geistesgeschichte des Mittelalters, v. 23. Berlim/Stuttgart/Hanover: Weidmann/ Hiersemann/Hahniani, 2008, dedica a ela todo o capítulo 9 (p. 40-52), um dos mais longos de sua obra.

${ }^{31}$ ERMENGALDO DE BÉZIERS. Opusculum contra haereticos, op. cit., 14, col. 1262d; PEDRO DES VAUX-DE-CERNAY. Hystoria Albigensis, op. cit., I, 17, p. 18; MONETA DE CREMONA. Adversus catharos et valdenses, op. cit., III, 8, p. 275; SACCONI, Raniero. Summa de catharis et leonistis pauperibus de Lugduno, op. cit., p. 49, linhas 21-24. Além desses casos, ocorridos na mesma comunidade, realizava-se a reconsolatio quando o indivíduo passava de uma seita cátara a outra, cf. DONDAINE, Antoine. Les actes du concile albigeois de Saint-Félix de Caraman. In: Miscellanea Giovanni Mercati. Vaticano: Biblioteca Apostolica, v. 5, p. 331-332, 1944.

32 "Deus benignum non faciebat florere nec gramare nec hominum generatione vel animalium, sed hoc totum faciebat deus malignus", pregava Guilherme de Autier, cátaro de Montaillou, cf. depoimento de outro herege, tomado em outubro de 1320: Registre, v. I, p. 283.
} 
informa um tratado de 1260-1270, os Perfeitos cumpriam três quaresmas anuais, no Natal, na Páscoa e em Pentecostes, durante as quais passavam a pão e água três dias por semana e todos os dias da primeira e da última semana de cada uma das quaresmas. ${ }^{33}$ Era tal a rejeição à alimentação carnívora que, para evitar ingerir legumes ou peixe tocados por ela, os "bons homens" viajavam com a própria panela. Se pelas circunstâncias eles eram obrigados a recorrer a um utensílio alheio, lavavam-no cinco vezes antes de preparar a comida. ${ }^{34}$

Os hereges insistiam sobre as "grandes abstinências" de seus boni homines opostas à glutoneria dos clérigos, e por isso no Sul francês, desde fins do século XII, "comer carne" tornou-se sinônimo de conversão ao catolicismo. ${ }^{35}$ É verdade que, tanto quanto os Perfeitos cátaros, os santos católicos também evitavam comida de origem animal, ou seja, a prática utópica, geradora de pureza — "o moralista em essência é um utopista”36 — era a mesma, a fundamentação ideológica e a mítica é que divergiam: para os cátaros, a carne é matéria, portanto criação do Deus mau; para os católicos, ela não é má em si mesma, já que criação de Deus, o uso dela é que pode ser inadequado em certos momentos (dias de jejum) e para certas pessoas (religiosos).

O segundo traço utópico do catarismo é a proposta de certa igualdade social. Para a seita é Satanás que dá a alguns humanos o domínio sobre outros, criando reis, condes e imperadores, ${ }^{37}$ afirmativa que retirava o caráter sagrado que a Igreja reconhecia aos governantes e, dessa forma, subvertia a ordem terrena. Não é casual que os primeiros grupos taxados de heréticos, na década de 1020, tenham coincidido com o progresso da institucionalização da Igreja romana, que despertou o anticlericalismo em muitos, inclusive nos cátaros. Tampouco surpreende que, ao contrário da Igreja centralista, hierárquica e misógina, no interior da Igreja cátara houvesse uma situação mais igualitária. Enquanto a sociedade católica estava dividida cada vez mais rigidamente entre clérigos e leigos, e a passagem dessa condição àquela era restrita (ou mesmo impossível, no caso das mulheres), na comunidade cátara a fronteira entre perfecti e credenti estava sempre aberta.

$\mathrm{O}$ crente que quisesse se tornar perfectus frequentava uma escola cátara por certo tempo, submetia-se a prolongado jejum (três vezes por semana durante um ano, às vezes mais) e por fim recebia o consolament, no qual todos os Perfeitos presentes impunham a mão sobre quem recebia a ordenação, ${ }^{38}$ diferentemente do rito católico, monopolizado pelo bispo. Ao contrário da Igreja católica, sobretudo gregoriana, a Igreja cátara apresentava or-

\footnotetext{
${ }^{33}$ A obrigação de orar é comunicada pelo Rituel cathare, op. cit., p. 220, linhas 13-17, e pelo Rituel provençal, CLÉDAT, Léon (Ed.). In: Le Nouveau Testament traduit au XIII siècle en langue provençale suivi d'un rituel cathare. Paris: Leroux, 1887, p. XXII. Os jejuns dos perfectos são informados por ANSELMO DE ALEXANDRIA. Tractatus de hereticis, op. cit., 7-6, p. 315.

${ }^{34}$ Registre, v. III, p. 153; v. II, p. 77.

${ }^{35}$ Registre, v. II, p. 24; DUVERNOY, Jean. La religion des cathares [1976]. Toulouse: Privat, 1996, p. 173.

${ }^{36}$ BENDA, Julien. La trahison des clercs [1927]. Paris: Grasset, 1995, p. 179.

${ }^{37}$ Registre, v. II, p. 461-462.

${ }^{38}$ Rituel cathare, op. cit., 14, p. 256, linhas 28-30.
} 
ganização atomizada (não havia um poder central como o papado) e pouco hierarquizada (somente episcopus, filius major, filius minor, diaconus). Para os hereges a pretensáo da Igreja ser universal ("católica") é "vanum et ridiculosum", conforme um texto de 1206-1208. ${ }^{39}$ Aliás, contrastando com a rígida hierarquia católica, os cátaros elegiam (pelo menos até 1250) os bispos de cada comunidade e seus concílios praticavam uma "democracia direta", na expressão de Jean Duvernoy. ${ }^{40}$

Outro aspecto a marcar a igualdade social cátara era o tipo de relacionamento entre sacerdotes e fiéis, patente no fato de os Perfeitos pregarem em língua vulgar, ao contrário dos padres ("pais", designação hierárquica) católicos que usavam o latim, entendido por pouca gente. Ademais, enquanto no catolicismo os sacerdotes são profissionais justificados pelo fato de que "quem serve ao altar participa do altar", de que "Deus ordenou a quem anuncia o Evangelho de viver do Evangelho", ${ }^{41}$ no catarismo os ministros exercem atividades comuns (da mesma forma que os apóstolos de Cristo): são pastores, camponeses, artesãos, mercadores, médicos. Paul Ourliac pensa que o comércio era a atividade preferida dos cátaros, com o que concorda René Nelli, alegando a superioridade moral daquele trabalho, já que o camponês produz coisas materiais, o artesáo transforma a matéria e o mercador apenas a vende, além do que o fato de viajar com frequência por mercados e feiras permitia a atividade evangelizadora. Nelli estima que entre 1200 e 1250 o catarismo pouco atraiu os camponeses, que para Jean Guiraud, porém, constituiam a "imensa maioria" dos hereges do Midi francês. ${ }^{42}$

Nem todos cátaros eram de condição econômica necessariamente próxima, mas todos participavam da produção de riquezas. Assim como os boni homines eram exaltados pelos hereges por trabalharem com as próprias mãos, diferentemente dos dominicanos que os combatia e não construíam suas grandes casas com esforço pessoal, ${ }^{43}$ o dízimo católico era criticado por transferir bens de quem produz para quem náo produz. Mais ainda, os hereges condenavam o falso perdão concedido em troca de dinheiro: em 1317, dois séculos antes da crítica luterana às indulgências, o último bonus christianus da Occitânia, Guilherme Bélibaste, afirmou que todo padre repetia "dê-me uma moeda e darei mil perdôes". Se eles

\footnotetext{
${ }^{39}$ As ordens cátaras estão descritas por SACCONI, Raniero. Summa de catharis et leonistis pauperibus de Lugduno, op. cit., p. 48-49. A crítica à catolicidade da Igreja é da Manifestatio haeresis albigensium et lugdunensium. In: Dondaine, Antoine (Ed.). Durand de Huesca et la politique anticathare. Archivum Fratrum Praedicatorum, v. 29, p. 268, linha 21, 1959.

${ }^{40}$ ANSELMO DE ALEXANDRIA. Tratactus de hereticis, op. cit., p. 309, linhas 8-18, p. 310, linhas 1-10; De heresi catharorum in Lombardia. In: Dondaine, Antoine (Ed.). Hiérarchie cathare en Italie. Archivum Fratrum Praedicatorum, v. 19, p. 306, linha 20, p. 308, linhas 7-8, 1949; DUVERNOY, Jean. La religion des cathares [1976], op. cit., p. 243.

${ }^{41} 1$ Coríntios IX, 13-14.

${ }^{42}$ OURLIAC, Paul. La société languedocienne du XIII ${ }^{e}$ siècle et le droit romain. In: Le Credo, la Morale et l'Inquisition. Toulouse: Privat, 1971 (Cahiers de Fanjeaux, 6), p. 206; NELLI, René. La vie quotidienne des cathares du Languedoc au XIII siècle. Paris: Hachette, 1969, p. 28, 54, 130; GUIRAUD, Jean. Histoire de l'Inquisition au Moyen Age. Paris: Auguste Picard, 1938, p. 356. v. I.

${ }^{43}$ Registre, v. II, p. 30; v. III, p. 95-96.
} 
assim faziam era por causa de Satanás, isto é, do papa, que explora todos os cristãos, "suga o sangue e o suor desta pobre gente". Enquanto os padres "roubam todos os bens dos homens", afirmou em 1322 uma herege, a Igreja cátara não explora seus seguidores. Ela não age como os Mendicantes (principal instrumento de Roma contra os hereges), definidos por outro cátaro como "lobos que na vida e na morte nos querem devorar". Aliás, o pároco católico da aldeia de Montaillou reconheceu exercer seu ministério apenas para obter os rendimentos correspondentes. ${ }^{44} \mathrm{~A}$ uns dez quilômetros dali, na aldeia de Tignac, antecipando em séculos o anticlericalismo revolucionário de 1789 ("quando o último rei for enforcado com os intestinos do último padre, o gênero humano poderá esperar ser feliz"), em 1321 um herege sonha em voz alta durante conversa com amigos: "Ah!, se todos os padres do mundo fossem enforcados!"45

Quando um herege declara que "nenhum rico pode ser salvo", ${ }^{46}$ ele pensa nos católicos, já que no interior da comunidade cátara não havia grande distância social, lá tudo deve ser comum a todos ("quod non debet possidere nisi in communi Ecclesia Dei nec potest"), denuncia uma lista católica de erros da heresia. ${ }^{47}$ Os perfecti não podiam ter propriedade pessoal, viviam do próprio trabalho e de doaçóes em gêneros alimentícios, roupas ou dinheiro. $\mathrm{Na}$ visão cátara, a sociedade terrena ideal, dentro do que era possível para algo construído na materialidade e cuja meta era justamente ultrapassar essa materialidade, deveria ter certos pontos básicos. Viver do próprio trabalho era uma delas. Como ocorre com qualquer comunidade, organismo vivo que tem dinâmica própria, a composição social do catarismo parece ter se alterado no decurso do tempo, e na direção de certa plebeização que se pode imaginar ter se devido, ao menos em parte, à sua proposta igualitária. Nos séculos XII-XIII o catarismo teve grande aceitação entre as camadas mais abonadas, no XIV popularizou-se entre trabalhadores urbanos e rurais, como indica o tratamento social de senher então aplicado a eles, no XV a heresia continuou forte entre as camadas mais modestas. ${ }^{48}$

A melhor expressão do desejo de igualdade na sociedade cátara talvez estivesse nas relaçôes de gênero. Embora no Midi católico as mulheres já desfrutassem de situação superior à do Norte francês, ${ }^{49}$ a condição feminina no catarismo parece ter sido melhor do que na sociedade feudal circundante. $\mathrm{O}$ sacerdócio, interditado às mulheres no catolicismo sob a argumentação que a impureza feminina impede o contato com o sagrado, estava aberto

\footnotetext{
${ }^{44}$ Registre, v. II, p. 26, 79, 25 (cf. também p. 54), 404, 30; v. I, p. 227; v. II, p. 109.

45 A célebre divisa revolucionária foi registrada em 1729 por MESLIER, Jean. Mémoires des pensées et sentiments. Edição de Roland Desné. Paris: Anthropos, 1974 (Euvres complètes, v. 1), p. 23, o comentário herético pelo Registre, v. II, p. 109.

${ }^{46}$ Registre, v. I, p. 457.

${ }^{47}$ Herrores heretiquorum, op. cit., p. 215.

${ }^{48}$ BIGET, Jean-Louis. Un procès d'inquisition à Albi en 1300. In: Le Credo, la Morale et l'Inquisition, op. cit., p. 298; DUVERNOY, JEAN. La religion des cathares [1976], op. cit., p. 172 e 263.

${ }^{49}$ Boa síntese em VERDON, Laure. La femme en Roussillon aux XII et XIII siècles. Statut juridique et économique. Annales du Midi, v. 227, p. 293-309, 1999.
} 
a elas no catarismo. As perfectae estavam tomadas pelo Espírito Santo tanto quanto seus correspondentes masculinos, podendo assim ministrar o consolamentum e ser objeto do melioramentum, isto é, das três reverências ou genuflexôes que os crentes realizavam diante dos ministros exatamente para venerar o Espírito Santo que se encontrava neles.

A igualdade social refletia a da vida espiritual. A confissão pública mensal não era ato pessoal, dava-se pela recitação de uma fórmula - "numerosos são nossos pecados, através dos quais ofendemos a Deus todo dia por palavras, açóes e pensamentos, com intençấo e sem intenção" - de maneira que a penitência não podia ser proporcional às faltas, era padronizada, era igual para todos, três dias de jejum e de genuflexôes. Havia equalitate mesmo em relação às recompensas que os humanos merecem e vão gozar..$^{50}$ Ao contrário do hierárquico Paraíso de nove esferas concêntricas descrito por Dante Alighieri em 1314-1320, pouco depois depoimentos de hereges à Inquisição referem-se ao Paraíso celeste como local onde todas as almas terão igual felicidade. ${ }^{51}$ Mesmo aquelas que não estiveram em corpos cátaros, pois Deus ama igualmente os batizados e os não batizados, "ama tanto os sarracenos e os judeus quanto os cristáos". ${ }^{52}$

Como observou René Nelli, a crença na reencarnação foi importante na visão social da seita: porque a alma podia migrar de um homem para uma mulher e vice-versa, o fato anulava "as desigualdades postuladas pela misoginia"; porque era possível a alma migrar de um nobre para um camponês e vice-versa, o fato esvaziava "toda superioridade de nascimento" e "arruinava a noção de hereditariedade". ${ }^{53}$ Sem ter intenção de exaltar a heresia, um cronista expóe o machismo católico diante da flexibilidade cátara ao narrar a forma pela qual o dominicano Étienne de Metz dirigiu-se à irmã do conde de Foix, protetora dos hereges, quando de um debate em Pamiers, em 1207: "senhora, vá fiar! Não interessa vossa fala num debate como este. ${ }^{34}$

No entanto, a igualdade de gênero era relativa. A repulsa cátara pelo sexo fazia com que as mulheres fossem vistas com certo receio. As perfectae eram quase sempre velhas e viúvas (da mesma forma que aconteceria mais tarde com as sacerdotisas na sociedade utopiana), ${ }^{55} \mathrm{e}$ não podiam ocupar os postos mais altos da enxuta hierarquia eclesiástica cátara. Quando o rito da imposição da mão era dirigido a uma mulher, os perfecti evitavam tocar-lhe a cabeça. Um simples toque sobre uma mulher provocava um jejum de nove dias a pão e água. ${ }^{56} \mathrm{~A}$

\footnotetext{
50 PREPOSTINO DE CREMONA, Summa contra haereticos, op. cit., XIV, p. 185, linhas 3-4 ("premia omnia equalia"), p. 186, linha 22 ("equales gloria erunt").

${ }^{51}$ É o caso de um depoimento de outubro de 1321 (Registre, v. II, p. 179), outro de novembro de 1322 (v. II, p. 411), outro ainda de julho de 1323 (v. III, p. 245).

52 Registre, v. II, p. 110, 111 e 113.

${ }^{53}$ NELLI, René. La vie quotidienne des cathares du Languedoc au XIII siècle, op. cit., p. 18 e 21.

${ }^{54}$ GUILHERME DE PUYLAURENS. Chronica/Chronique, 1145-1275, op. cit., VIII, p. 54.

55 MONETA DE CREMONA. Adversus catharos et valdenses, op. cit., IV, II, p. 293; MORE, Thomas. L'Utopie, op. cit., II, p. 228, linhas 17-18.

${ }^{56}$ Registre, v. III, p. 111.
} 
mesma desconfiança em relação ao feminino levou o já citado Guilherme Bélibaste a explicar que o ciclo de reencarnaçóes só pode ser interrompido para uma mulher quando sua alma estiver em corpo masculino. Na aldeia de Tignac, Arnaldo Laufre afirmou que "a alma de uma mulher e a alma de uma porca são iguais, isto é, não valem grande coisa". ${ }^{57}$ Mas não se deve exagerar o alcance dessas opinióes misóginas pessoais e tardias. Na sociedade cátara clássica a mulher podia exercer profissóes, tinha certa liberdade sexual (no caso das simples crentes, já que as perfectae, como seus colegas homens, adotavam abstinência total e definitiva), chefiava a família no caso de falecimento do homem.

Terceiro traço utópico, estreitamente associado ao anterior, é o sentimento de fraternidade. Quando em Colônia, em 1163, foram condenados quatro cátaros homens, a mulher do grupo jogou-se (promittentium) espontaneamente na fogueira, por solidariedade. ${ }^{8}$ Por volta de 1300, no mercado de Tarascon, uma comerciante de cereal entregou a um cátaro uma quantidade maior do que ele havia comprado, e justificou: "a totas gens fay be, for maiorment en aqueli de la fe!" (faça o bem a todos, especialmente àqueles da mesma fé). ${ }^{59}$ Sendo todo crestia "amigo de Deus", ${ }^{60}$ por meio deles reforçava-se a consciência de pertencimento à comunidade e assim à rede de fraternidade dos cátaros, graças ao que, contou Evervino a São Bernardo, podiam facilmente suportar perseguição, martírio, abstinência, trabalho, porque "não somos deste mundo". ${ }^{61}$

Partindo de uma passagem paulina, os cátaros insistiam sobre a importância da caridade, que na prática cotidiana servia de forte cimento social para a seita. É o que comprova o fato de os hereges aceitarem de bom grado dar esmolas para os "bons homens", mas não para os católicos, ${ }^{62}$ o que de acordo com outro cátaro seria mesmo pecado. ${ }^{63}$ Nelli supóe que por serem "muito escrupulosos em matéria de retribuição", os cátaros donos de oficinas de

${ }^{57}$ Registre, v. II, p. 441-442 (Bélibaste) e 131 (Laufre). Em certos grupos cátaros, como em Desenzano (na Lombardia, perto de Brescia) ou tardiamente no Languedoc, a ideia da reencarnação derivou para a versão mais radical da metempsicose, transmigração da alma inclusive para corpos de outras espécies.

58 CESÁRIO DE HEISTERBACH. Dialogus miraculorum, V, 19. Edição de Joseph Strange. Colônia: J. M. Heberle, 1851. 2v. STRANGE, Joseph (Ed.). Colônia: J. M. Heberle, 1851, v. I, p. 299; Chronica regia Coloniensis. In: Waitz, Georg (Ed.). Monumenta Germaniae Historica. Rerum germanicarum in usum scholarum, v. 18. Berlim/Stuttgart/Hanover: Weidmann/Hiersemann/Hahniani, 1880, p. 114; Annales Aquenses, anno 1163. In: Pertz, Georg H. (Ed.). Monumenta Germaniae Historica. Berlim/Stuttgart/ Hanover: Weidmann/Hiersemann/Hahniani, 1859, p. 686. v. 16. linhas 25-26.

${ }^{59}$ Registre, v. II, p. 108.

${ }^{60}$ Por exemplo, Registre, v. II, p. 513 et passim; Confessiones de V libro Lauraguesii Fratris Bernardo de Cautio transcripto. Toulouse: Bibliothèque Municipale, ms. 609, fol. 5 et passim. A expressão é reflexo de Tiago IV, 4: "quem quiser ser amigo do mundo constitui-se em inimigo de Deus".

${ }^{61}$ Epistola ad S. Bernardum, 3, col. 678a.

${ }^{62}$ Registre, v. II, p. 501; v. I, p. 457. Cf. também Tractatus manicheorum, XIII. In: THOUZELLIER, Christine. Un traité cathare inédit du début du XIII siècle d'après le Liber contra Manicheos de Durand de Huesca. Louvain: Université de Louvain, 1961, p. 102 (cf. 1 Coríntios VIII, 4). Outra fonte nega a boa vontade cátara em dar esmolas, mas confirma que elas inexistiam em relação a forasteiros: SACCONI, Raniero. Summa de catharis et leonistis pauperibus de Lugduno, op. cit., p. 47, linha 9 ("eleemosynas paucas aut nullas faciunt, nullas extraneis"). ${ }^{63}$ Registre, v. I, p. 457 ("peccatum erat facere elomosinam catholicis"). 
tecelagem, atividade muito comum entre eles, remuneravam melhor seus correligionários. ${ }^{64}$ $\mathrm{Na}$ regiāo da alta Ariège, fortemente catarizada, a contestação antinobiliárquica foi muito rara, notou Ladurie. ${ }^{65} \mathrm{O}$ fato pode ter simplesmente decorrido das condiçóes gerais de uma sociedade camponesa-pastoril de zonas montanhosas, onde as duras condiçóes de vida aproximam as pessoas, criam laços de solidariedade independentemente de origem social. Mas pode também ser creditado ao nivelamento social que se percebe em vários aspectos da vida nas comunidades cátaras.

Quarto traço a ser observado, o forte desejo de justiça, cujo espírito de certa forma acompanhava o da liturgia: um minimalismo eficiente, ao alcance de todos, náo apenas de uma elite instruída ou rica. A comunidade cátara pautava-se pelo mesmo princípio que séculos depois Thomas More atribuiria à sua Utopia: as leis são poucas e simples, pois quanto mais leis existem menos reina a justiça, dirá o jurista e humanista inglês. ${ }^{66} \mathrm{~A}$ concepção de justiça dos cátaros era bem menos formalista que a da sociedade global, por ver nela muito mais do que a aplicação social de um princípio moral, tratava-se de um elemento metafísico - "injustiça" é um dos muitos nomes do principium mali. ${ }^{67}$

Os cátaros estavam proibidos de mentir, matar, julgar e jurar. ${ }^{68} \mathrm{~A}$ interdição deste último ato é significativa, pois ao negar qualquer valor jurídico e moral ao juramento contestava-se o procedimento que se constituía na base da sociedade feudoclerical. Não é neutro o fato de a traduçáo occitana de uma passagem do Apocalipse ter substituído no juramento do anjo a palavra "mão" ("levavit manum suam ad caelum") pela palavra "voz" ("et l'angel leves la sua votz al ciel”). Os "bons homens" não podiam jurar em circunstância alguma, mas aceitava-se que os crentes o fizessem para ocultar elementos doutrinários do catarismo de pessoas externas à seita, sobretudo de inquisidores. Quando era preciso estabelecer um laço contratual, fosse social ou comercial, fazia-se "per la fe de son cors", isto é, pela palavra de honra selada com um duplo beijo na boca (bis in ore ex transverso). ${ }^{69}$

\footnotetext{
${ }^{64}$ NELLI, René. La vie quotidienne des cathares du Languedoc au XIII siècle, op. cit., p. 123-124.

${ }^{65}$ LADURIE, Emmanuel Le Roy. Montaillou, povoado occitânico, 1294-1324 [1975]. São Paulo: Companhia das Letras, 1997, p. 344.

${ }^{66}$ MORE, Thomas. L'Utopie, op. cit., I, 65, linhas 9-10, II, p. 125, linhas 12-13.

${ }^{67}$ SACCONI, Raniero. Summa de catharis et leonistis pauperibus de Lugduno, op. cit., p. 52, linha 23.

${ }^{68}$ Tais interdiçôes são testemunhadas tanto por textos heréticos quanto contrários a eles. Dentre os primeiros, Rituel cathare, op. cit., 13, p. 250, linhas 35-37; Un recueil cathare: le manuscrit de Dublin, VII, p. 825826; Rituel provençal, op. cit., p. X, XIX, XXIII. Dentre os segundos, ERMENGALDO DE BÉZIERS, Opusculum contra haereticos, op. cit., 18, col. 1269-1272; PEDRO DES VAUX-DE-CERNAY, Hystoria Albigensis, op. cit., I, 13, p. 14; SACCONI, Raniero, Summa de catharis et leonistis pauperibus de Lugduno, op. cit., p. 43, linhas 10-11; Herrores heretiquorum, op. cit., p. 215 e 216; Registre, v. I, p. 230, v. II, p. 52, v. III, p. 131 e 246; BERNARDO GUI. Manuel de l'inquisiteur, I, 2 e 4. MOLLAT, Guillaume (Ed./Trad.). Paris: Les Belles Lettres, 2006, v. I, p. 18-19 e p. 24-25.

${ }^{69}$ Apocalipse X, 5. A citação bíblica é extraída de Le Nouveau Testament traduit en langue provençale, p. 282, coluna esquerda, linha 2. As exceçóes à proibição de prestar juramento estão em Rituel provençal, op. cit., p. XVIII; Registre, v. III, p. 246.
} 
Alegando a proibição veterotestamentária de matar e duas passagens neotestamentárias de repúdio à vingança, o catarismo negava que o poder público pudesse condenar alguém à pena capital, direito reservado apenas a Deus: "Os senhores temporais pecam mortalmente quando executam ou fazem executar assassinos, ladróes e outros malfeitores"; um adepto do catarismo não deve sequer prestar testemunho em justiça de um homicídio a que tiver presenciado. ${ }^{70}$ Do ponto de vista cátaro, o fato de o Antigo Testamento aceitar a vingança coletiva apenas comprovava que ele tinha sido escrito pelo Diabo. ${ }^{71} \mathrm{O}$ que se deveria buscar é a justiça maior, aquela que liberta a alma da prisão (carcer em occitano, carcere em latim, diz a documentação) do corpo, cuja morte deve ser definitiva e não apenas mais uma do longo ciclo no qual as sucessivas mortes representam meras mudanças de "tunicas, id est corpora" ${ }^{72}$ Ou seja, levar vida justa é meio de evitar a passagem da alma para outro corpo, humano ou animal - "Senhor, tenha piedade do espírito que está aprisionado", proclamou entre 1250 e 1280 um texto ritual. ${ }^{73}$

A crença na metempsicose tinha precedentes ocidentais em especulaçôes pagãs clássicas (orfismo, pitagorismo, empedoclismo e platonismo) e cristãs primitivas (origenismo) que não chegaram, todavia, a definir comportamentos sociais de toda uma comunidade, como ocorreu entre os cátaros. Por exemplo, devido à metempsicose os "bons cristãos" não apenas não podiam matar, como também tinham preocupação cotidiana em preservar a vida, como demonstra o exemplum cátaro que fala de dois deles que encontram em uma floresta um esquilo preso em uma armadilha. Sabendo que no pequeno animal podia estar uma alma, soltam-no e no lugar deixam algumas moedas para não prejudicar o caçador que vivia desse trabalho. ${ }^{74}$

A crença na metempsicose levou alguns hereges às garras da Inquisição, para a qual a recusa de alguém em matar um animal era claro indício de catarismo: em 1247 duas mulheres de Châteauverdun foram condenadas por terem se recusado a abater galinhas para co-

\footnotetext{
${ }^{70}$ Éxodo XX, 13, Romanos XII, 19 e Hebreus X, 30; Registre, v. II, p. 122, 115.

${ }^{71}$ SACCONI, Raniero, Summa de catharis et leonistis pauperibus de Lugduno, op. cit., p. 43, linhas 12-13; ANDRÉ FLORENTINO, Summa contra hereticos, 6, op. cit., p. 20. A procedência diabólica do Antigo Testamento é referida por ERMENGALDO DE BÉZIERS. Opusculum contra haereticos, op. cit., 3, col. 1237c; PEDRO DES VAUX-DE-CERNAY. Hystoria Albigensis, op. cit., I, 10, p. 9-10; MONETA DE CREMONA. Adversus catharos et valdenses, op. cit., I, I, prefácio, p. 5-6; II, VI, 4, p. 163-165 e II, VII, 1, p. 196-203; SACCONI, Raniero. Summa de catharis et leonistis pauperibus de Lugduno, op. cit., p. 51, linha 30, p. 58, linhas 9-10; Herrores heretiquorum, op. cit., p. 214. E é insinuada pelo De heresi catharorum in Lombardia, p. 309, linhas 7-8, onde o Diabo é chamado de mentiroso (mendax), mesma palavra usada pela Hystoria Albigensis para qualificar os autores do Antigo Testamento.

${ }^{72}$ Registre, v. III, p. 220. A concepção do corpo como prisão da alma (que teria aparecido com o pré-socrático Filolau, conforme o testemunho bem posterior de Clemente de Alexandria) está no primeiro utopista [PLATÃO, Phédon, 62b, Edição de Léon Robin. Tradução de Monique Dixsaut. In: Platon, ceuvres complètes. Organização de Luc Brisson. Paris: Flammarion, 2009, p. 1177] e no mais famoso deles (MORE, Thomas. L'Utopie, op. cit., II, p. 120, linhas 9-10).

73 "Senhor (...) aias merce del esperit pausat en carcer": Rituel provençal, op. cit., p. XI.

${ }^{74}$ Registre, v. II, p. 107 e v. III, p. 306.
} 
zinhar. ${ }^{75}$ Por não aceitarem o dogma católico da ressurreição dos corpos, ${ }^{76}$ os cátaros pouco inumavam, no mais das vezes limitavam-se a enterrar os cadáveres (nus ou apenas envolvidos por um lençol) num porão ou jardim ou mesmo a jogá-los num rio ou poço, ${ }^{77}$ o que se fazia sem cerimônia alguma, sem preces ou presença de bos crestias. O próprio conceito de cemitério não fazia sentido para eles. Aquilo que modernamente se chama, às vezes, de cemitérios cátaros, eram apenas depósitos de corpos sem sepulturas identificadas. Tratava-se de locais banais, sem nada de sagrado, ao contrário dos cemitérios católicos, pois a materialidade de qualquer terreno impede que ele seja sagrado para os adeptos do catarismo.

O desejo de apressar o fim das reencarnaçôes levou alguns cátaros franceses a praticarem a partir de 1273, no contexto das grandes perseguições que então sofriam, a endura, suicídio religioso não obrigatório para os doentes terminais que já haviam recebido o consolament. Esse gesto de magnum meritum era geralmente a abstenção total de alimento (em occitano endura é, literalmente, "privação”, “jejum”), mas podia se dar também por sangramento ou envenenamento voluntários. Como quer que fosse, o suicídio era "o meio mais rápido de atingir a perfeição espiritual”, avalia Guiraud. ${ }^{78}$ Embora seu catolicismo tornasse a metempsicose inaceitável, Thomas More admite a existência de alma nos animais e atribui aos utopianos uma prática semelhante à endura cátara. Na ilha da Utopia, quando o doente não tem esperança de cura e viver é sofrido, está autorizado a se evadir dessa vida ou a permitir que outras pessoas o façam por ele. Alguns se deixam morrer de fome ou são adormecidos e liberados sem mesmo sentir que morrem: morrer assim, aconselhado pelos padres, é, aos olhos deles, ato de santa piedade. ${ }^{79}$

Quinto traço utópico, a sociedade cátara idealizava um mundo de paz, sem violência, daí a já referida estrita interdição de matar. Além disso, o ritual cátaro incita a perdoar as ofensas

\footnotetext{
${ }^{75}$ Registre, v. I, p. 221. Outro exemplo, mais ou menos da mesma época, relativo a um indivíduo de Toulouse, aparece no Fonds Jean Doat. Paris: Bibliothèque Nationale, ms. nouv. acq. fr. 22765, v. 25, fol.42rv. A estratégia de forçar um suspeito a comer carne, ou ao menos legumes cozidos com carne, já tinha sido determinada pelo Concílio de Braga, em 561, para combater o priscilianismo: Concilios visigóticos e hispano-romanos. Edição e tradução de José Vives. Barcelona/Madri: CSIC/Instituto Enrique Flórez, 1963, p. 74. A prática tornou-se comum na identificação de cátaros, como reconhece um inquisidor do século XIV (Fonds Doat, v. 36, fol. 54-55).

${ }^{76}$ ANDRÉ FLORENTINO, Summa contra hereticos, op. cit., 19, p. 124-139; Registre, v. I, p. 204-206 e 447; v. II, p. 179, 409 e 498-499; v. III, p. 8, 242.

${ }^{77}$ Registre, v. III, p. 347; Le livre des sentences de l'inquisiteur Bernard Gui, 1308-1323, PALES-GOBILLIARD, Annette (Ed./Trad.). Paris: CNRS, 2002, v. I, p. 235, 238, 292 e 636; Fonds Doat, v. 22, fol. 47v e 49v, v. 26, fol. 16. GUILHERME DE PUYLAURENS, Chronica/Chronique, 1145-1275, op. cit., III, p. 38-39, fala de um indivíduo que declarou náo querer ser enterrado em mosteiro ou igreja, e sim ser transportado até os bonomios heréticos, o que subentende que entre eles seu corpo teria destino diferente.

${ }^{78}$ GUIRAUD, Jean. Histoire de l'Inquisition, au Moyen Age, op. cit., v. I, p. 80. A endura aparece 20 vezes nos processos inquisitoriais realizados pelo bispo de Pamiers (cf. o Índice do Registre, v. III, p. 540), 17 vezes nas sentenças pronunciadas na mesma época por um inquisidor dominicano (Índice de Le livre des sentences, v. II, p. 1789), seis vezes nos interrogatórios feitos por outro dominicano (Acta inquisitionis Carcassonensis contra Albigenses ann. 1308 et 1309. In: Pales-Gobilliard, Annette (Ed./Trad.). L'inquisiteur Geoffrey d'Ablis et les cathares du comté de Foix (1308-1309). Paris: CNRS, 1984. p. 418). A definição da morte em endura como feito de "grande mérito" aparece em um dos depoimentos à Inquisição (Registre, v. III, p. 247).

${ }^{79}$ MORE, Thomas. L'Utopie, op. cit., II, p. 145, linhas 20-23; II, p. 120, linhas 2-16.
} 
recebidas e inclusive a amar o inimigo ("qui li fa mal, e que hom ame sei enemic"). ${ }^{80}$ Assim, não era meramente formal que o aparelhament e o consolament sempre terminassem com $\mathrm{o}$ beijo de paz. Um Perfeito beijava um ou vários crentes que a seguir se beijavam entre si, nas duas faces e na boca, para bem marcar a coesão espiritual da comunidade. Para incluir as mulheres sem tocá-las, o perfectus beijava um exemplar do Evangelho de João que depois era beijado por elas antes de se beijarem mutuamente.

A ideia de paz era extensiva aos animais, que se evitava matar por seus corpos abrigarem almas que já haviam se instalado ou poderiam vir a se instalar em corpos humanos. Uma narrativa bem difundida nos meios cátaros do Sul francês de princípios do século XIV falava de certa alma que ao deixar um homem instalou-se em um cavalo e depois da morte deste voltou a um corpo humano. ${ }^{81}$ Abater um animal para devorar sua carne era violência não contra a matéria, que os cátaros desprezavam — na bela expressão de Ladurie, para eles "a vida não é mais que uma doença mortal"s2 - e sim contra uma alma. Por isso a carne era chamada de fereza ("selvageria", do latim feritas), alimento degradante por resultar de ato desumano.

O pacifismo dos boni christiani era tão radical — "não é lícito matar quem quer que seja" — que os deixou à mercê de seus inimigos e acelerou a dissolução da comunidade cátara. No evento mais famoso, durante o cerco ao castelo de Montségur, entre maio de 1243 e março de 1244, por parte de várias centenas de homens comandados pelo arcebispo de Narbonne, a defesa ficou a cargo de poucas dezenas de guerreiros, entre crentes e mercenários, enquanto os proporcionalmente muitos ministros cátaros ali presentes continuaram a rezar, a trabalhar, a cuidar dos feridos e a conferir consolamenta aos moribundos, sem participar diretamente da luta. Da mesma forma que todo herege e todo utopista, os cátaros (ao menos os perfecti) eram dotados de forte convicção, em nome da qual preferiam morrer que renunciar: na cerimônia de ordenação, diz o ritual, o bon homme compromete-se a "não fazer defecção por nenhum motivo". Aliás, conta Evervino, os cátaros que em Colônia foram levados à fogueira "suportaram o suplício do fogo não somente com paciência, mas mesmo com alegria". ${ }^{84}$ É isso também, informa Lucas de Tuy, que ocorreu com os cátaros executados em 1230 em León. ${ }^{85}$

Sexto traço, a idealização do passado. Como toda utopia e toda heresia, o catarismo propunha uma subversão radical do seu presente, cujas deficiências pretendia superar por meio

\footnotetext{
${ }^{80}$ Rituel provençal, op. cit., p. XVIII, cf. Mateus V, 21.

${ }^{81}$ Registre, v. II, p. 36, 408 e 491, v. III, p. 138 e 221.

${ }^{82}$ LADURIE, Emmanuel Le Roy. Montaillou, povoado occitânico, 1294-1324 [1975], op. cit., p. 469.

${ }^{83}$ Herrores heretiquorum, op. cit., p. 215.

${ }^{84}$ Rituel cathare, op. cit., 14, p. 254, linha 7; Epistola ad S. Bernardum, 2, col. 677c.

${ }^{85}$ LUCAS DE TUY. De altera vita. In: Rey, Emma Falque. Corpus Christianorum Continuatio Medievalis. Turnhout: Brepols, 2009, v. 74A, III, 21, p. 223, linhas 3-4. Essa "alegria" decorria da certeza de sua fé em contraste com a dos torturadores, isto é, eles tinham consciência das diferenças entre seu cristianismo e o dos clérigos, daí nos parecer exagerado dizer (como faz PEGG, Mark G. A Most Holy War. The Albigensian Crusade and the battle for Christendom. Oxford: Oxford University Press, 2008) que antes da Cruzada Albigense não houve heresia ou dissidência vividas como tais.
} 
do retorno a uma situação anterior modelar — no caso, os tempos apostólicos — mais do que pelas promessas do futuro. ${ }^{86}$ De fato, na comunidade cátara orava-se em pé, acompanhado por várias prosternaçôes e genuflexôes, palmas das mãos voltadas para o céu e, possivelmente, o corpo para o Oriente, como tinha sido a postura do orante na Antiguidade cristá. Do cristianismo primitivo provinham ainda o costume de os bispos serem eleitos por toda a comunidade, a crença na preexistência e reencarnação das almas (que havia sido aceita por autoridades como Justino, Clemente de Alexandria, Tertuliano, Mario Victorino ou Gregório de Nissa) e o aparelhament. Bem como o elemento central de sua liturgia, o consolamentum. ${ }^{87}$ Daí a comunidade cátara de Colônia ter assegurado existir, escondida, desde o tempo dos mártires. ${ }^{88}$

Se as mulheres foram plenamente aceitas na comunidade cátara, como perfectae ou como credentes, foi porque os apóstolos tiveram mulheres no seu grupo. Se antes de receber o consolament que o tornaria um Perfeito, o indivíduo engajava-se a não matar, não jurar, não julgar, era por oposição às práticas sociais de seu tempo, mas igualmente por respeito estrito ao que prescrevem certas passagens evangélicas. ${ }^{89} \mathrm{O}$ catarismo, sem dúvida, fez parte do revigoramento da espiritualidade evangélica que o Ocidente conheceu a partir do século XI. E tornou-se uma heresia justamente por revelar, naquele momento de intensas transformaçóes globais da sociedade ocidental, a contradiçáo que de certa forma acompanha toda a história da Igreja - institucionalizar o espiritual, hierarquizar o igual, monopolizar o sagrado.

Também em função de seu espírito nostálgico é que todos os grupos heréticos tendiam à compreensão literal dos textos sagrados. Embora o grau de cultura literária tenha sido muito variado entre, por exemplo, o provavelmente analfabeto Leutardo e os eruditos cônegos de Orléans, os grupos heréticos do século XI constituíram, na expressão de Brian Stock, "comunidades textuais", isto é, cuja interpretaçâo dos textos estruturava o grupo e dava-lhe solidariedade diante do mundo exterior. $\mathrm{O}$ historiador estadunidense não diz, mas pensamos que aquela interpretação, independentemente das nuanças históricas, geográficas e sociológicas, era de entendimento literal do texto bíblico. A "religiâo mínima" que Leland Miles atribui à ilha da Utopia (bem como à República platônica) ${ }^{90}$ pode perfeitamente ser creditada às heresias medievais, cujo despojamento doutrinal e ritual devia-se aos traços do cristianismo primitivo adotados por todas elas.

\footnotetext{
${ }^{86}$ Fenômeno psicologicamente nostálgico, o catarismo não se afasta nisso da utopia monástica cujo modelo eram as primitivas comunidades cristãs (FRANCO JÚNIOR, Hilário. Nos confins do mundo, na vizinhança do Paraíso: a utopia monástica, op. cit.), nem da utopia moriana, que segue o exemplo da vida em comum nos tempos evangélicos (MORE, Thomas. L’Utopie, op. cit., II, p. 142, linhas 10-14).

${ }^{87}$ Rituel cathare, 12, op. cit., p. 246, linhas 27-28. Alguns estudiosos (entre os quais os já citados Guiraud, Nelli e Thouzellier) chamam mesmo os cátaros de "paleocristãos".

${ }^{88}$ EVERVINO, DE STEINFELD. Epistola ad S. Bernardum, op. cit., 6, col. 679d.

${ }^{89}$ Mateus V, 21; V, 34-36; VII, 1.

${ }^{90}$ STOCK, Brian. The implications of literacy: written language and models of interpretation in the eleventh and twelfth centuries. Princeton: Princeton University Press, 1983; MILES, Leland. The Platonic source of Utopia's minimum religion. Renaissance News, Chicago, v. 9, p. 83-90, 1956.
} 
O literalismo herético era aplicado náo somente aos textos, como ainda a objetos. Por exemplo, a recusa de muitas seitas ao caráter sobrenatural da água, do óleo, do vinho ou do pão usados sacramentalmente decorria da leitura literal, imediata, antimetafórica, que todo herege fazia do mundo. Ilustração disso, narrada pelo abade de Schönau, é a declaração de um cátaro de Bonn que negou a eucaristia argumentando que se nela realmente se comesse o corpo de Cristo, este deveria ter sido maior do que uma montanha. Em função desse olhar simples e ingênuo sobre as Escrituras, os cátaros foram taxados de "rusticani et idiotae" por Bernardo de Claraval. ${ }^{91}$ Em termos da filosofia da época, talvez se possa dizer que as heresias eram nominalistas, não aceitavam os universalia, as ideias gerais que precederiam as coisas. A Igreja acusou as heresias de fazerem "escolhas", mas rigorosamente falando ocorreu o inverso, estas entenderam literalmente o texto sagrado, quem fez escolhas foi o cristianismo oficial, que optou por interpretaçóes elaboradas, alegóricas, metafóricas, que buscam sentidos ocultos.

Em uma sociedade como a medieval, na qual a instância sagrada e a instância profana raramente estavam desconectadas, as manifestaçóes que séculos depois seriam rotuladas de religiosas não podiam deixar de ter facetas "políticas" e "econômicas". Ora, nos séculos XI-XII de aceleradas transformaçôes históricas, ao sentirem-se desamparados, ultrapassados, certos segmentos sociais agarraram-se ao modo de vida tradicional. O espírito do tempo estimulava essa postura, com sua valorização do passado tanto na cultura (o Renascimento do século XII) como na religiấo (o evangelismo, ortodoxo e heterodoxo). A pequena aristocracia provençal, por exemplo, aderiu à dissidência religiosa como parte da rejeição das novitates da época e como tentativa de manter a autonomia local, religiosa e política, diante do projeto unificador e centralizador da Igreja romana e da monarquia francesa.

\section{Considerações finais}

Se o catarismo tinha os mesmos traços que outras utopias não consideradas heréticas pela Igreja, por que foi tão violentamente combatido por ela? Justamente porque se confrontava com projetos semelhantes existentes no interior da Igreja. Em especial o monasticismo,

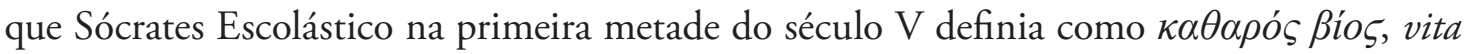
pura.92 O sentimento dos hereges "puros" ("cathari") estava muito próximo ao monástico "desprezo do mundo" ("contemptus mundi"). A pobreza evangélica que praticavam lembrava a da Ordem de Grandmont (cujos membros intitulavam-se "bons homens") e a da Ordem

\footnotetext{
${ }^{91}$ EGBERTO. Sermones contra catharos, op. cit., XI, 14, col. 92c; BERNARDO. Sermones in Cantica Canticorum, LXVI, I, 1. LECLERCQ, Jean; TALBOT, Charles H.; ROCHAIS, Henri M. (Ed.). Roma: Editiones Cistercienses, 1958 (S. Bernardi opera, II), p. 179, linha 2.

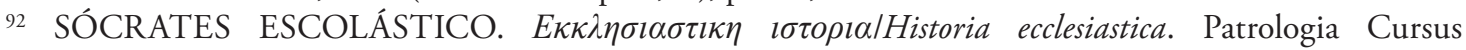
Completus. Series Graeca. Edição de Jacques-Paul Migne e Henri de Valois [1857-1886]. Turnhout: Brepols, 1984-1991 v. 67, IV, 23, col. 509d.
} 
Premonstratense (o que explica a indignação de um de seus cônegos, Evervino, diante da afirmação dos hereges: "nós somos os pobres de Cristo"”3).

Assim como os monges, os bos crestias rejeitavam toda relação sexual, comportamento semelhante ao dos anjos no Reino dos Céus ou ao de Adão e Eva no Éden. ${ }^{94}$ Os Perfeitos não comiam carne, ${ }^{95} \mathrm{da}$ mesma forma que os cistercienses que tanto os combateram. ${ }^{96}$ Mais precisamente, eles recusavam qualquer alimentaçáo de origem animal, a exemplo dos primi parentes que antes da Expulsão comiam apenas vegetais: a profissão de fé cátara incluía a declaração de "jamais, consciente ou voluntariamente, comer queijo, leite, ovos, carne de ave, de réptil ou de animal". ${ }^{97} \mathrm{~A}$ vida cotidiana dos ministros cátaros não era muito diferente da dos monges, excetuadas a clausura e a liturgia: vestiam-se de preto, andavam em dupla, durante a noite levantavam-se várias vezes para rezar, viviam em castidade, submetiam-se a jejuns e abstinências alimentares.

Os cátaros de Colônia declararam levar vida santa, "passando dia e noite a rezar e trabalhar", 98 isto é, praticando o ora et labora beneditino. Quando um herege cátaro de Castelnaudary (a 20 quilômetros a Sudeste de Toulouse) ficou doente em Narbonne durante uma viagem, em 1226, ao não encontrar ministros da sua seita e da sua regiáo que lhe dessem assistência espiritual adequada, apenas outros hereges em quem por alguma razão não confiava, preferiu ingressar no mosteiro cisterciense de Boulbonne. ${ }^{99}$ Esse episódio da petite histoire revela a percepçáo que muitos tinham do denominador comum entre o projeto monástico e o projeto cátaro.

Este atraiu assim indivíduos insatisfeitos com o cristianismo oficial, muito formal e ritual, que tinham a intenção de reformar — Ladurie observou, falando da aldeia pirenaica de Montaillou, que "o catarismo é vivido por aqueles que o adotaram como uma variante extrema e heroica do cristianismo, e não como uma religião não cristâ". ${ }^{100}$ Mais do que colocar em prática um corpo doutrinário coerente (criação da historiografia do século XIX), o catarismo procurava responder a certo mal-estar existencial, a certa insatisfação espiritual. Daí ter se espraiado por várias regióes europeias, embora seja difícil calcular o contingente total daquela seita, que teria atingido em "todo o mundo" a cifra de 4 mil ministros de

\footnotetext{
${ }^{93}$ EVERVINO, DE STEINFELD. Epistola ad S. Bernardum, op. cit., 4, col. 677d.

${ }^{4}$ A comparaçáo da sociedade cátara com a sociedade angélica fica sugerida pela Interrogatio Iohannis, p. 74, ms. V, linhas 187-188, ms. D, linhas 171-172; p. 80, ms. V, linhas 227-228, ms. D, linhas 210-211, cf. Mateus XXII, 30. A recusa à sexualidade, baseada em Gênesis IV, 1, é relatada por EGBERTO. Sermones contra catharos, op. cit., I, 2, col. 14b; PREPOSTINO DE CREMONA. Svmma contra haereticos, op. cit., IV, p. 66-71; PEDRO DES VAUX-DE-CERNAY. Hystoria Albigensis, op. cit., I, 13, p. 14; RALPH DE COGGESHALL. Chronicon anglicanum, op. cit., p. 124.

${ }^{95}$ É o que informam várias fontes, desde 1143 com o prior premonstratense EVERVINO DE STEINFELD. Epistola ad S. Bernardum, op. cit., 3, col. 678a, até 1318-1325 com o Registre, v. II, p. 33, 41 e 413; v. III, p. 137 et passim.

${ }^{96}$ A interdição carnívora aos cistercienses está nos Capitula cisterciensis ordinis, XIII, 2, e nos Instituta Generalis Capituli, XXIV, 1, ambos os documentos em Narrative and legislative texts from early Cîteaux. Edição de Chrysogonus Waddel. Cîteaux: Commentarii cistercienses, 1999 (Studia et Documenta, v. IX), p. 410, 466.

${ }^{97}$ Gênesis II, 16; Rituel cathare, op. cit., 13, p. 250, linhas 40-42.

${ }^{98}$ EVERVINO DE STEINFELD, Epistola ad S. Bernardum, op. cit., 3, col. 677d.

${ }^{99}$ Confessiones de Bernardo de Cautio, fol. 250v-251r.

${ }^{100}$ LADURIE, Emmanuel Le Roy. Montaillou, povoado occitânico, 1294-1324 [1975], op. cit., p. 435.
} 
acordo com alguém que conhecia bem o ambiente herético por ter feito parte dele durante 17 anos antes de se reconverter, em 1250, ao catolicismo. ${ }^{101}$ Não se sabe quantos crentes correspondiam a cada ministro, mas pode-se estimar que o universo cátaro no seu apogeu deve ter englobado algumas dezenas de milhares de indivíduos.

Por que, então, o catarismo desapareceu em fins do século XIII-princípios do XIV no Sul francês e um pouco depois no Norte italiano? A resposta historiográfica tradicional — a Inquisição - é aceitável apenas em parte. A explicação institucional-político-militar relega ao segundo plano o fenômeno socioespiritual que esteve na base do surgimento do catarismo. E da reação eclesial ao reconhecer o poder de atração que desde o século XI a vita apostolica exercia sobre o laicado, daí a institucionalização das Ordens dos Mendicantes. É expressivo que na Itália setentrional os cátaros tenham ficado conhecidos por "maltrapilhos" (patarini), nome dado desde a segunda metade do século XI aos puritanos surgidos em Milão para apoiar a Reforma gregoriana, mas que pelo seu radicalismo acabariam por ser heretizados. Na Toscana, o termo "patarino" tornou-se, desde 1173, intercambiável com "cátaro". ${ }^{102}$

Ora, na vizinha Úmbria existia ao menos uma comunidade daqueles hereges, em Spoleto, cidade que Francisco conhecia bem por estar a somente $45 \mathrm{~km}$ de sua Assis natal. Em 1209, logo depois de encontro com o papa, Francisco "dirigiu-se para o vale de Spoleto para aí viver e pregar o Evangelho de Cristo". ${ }^{103}$ Talvez para se opor à pregação cátara? Intencionalmente ou não, foi em Bevagna, a meio caminho entre Spoleto e Assis, que, voltando de Roma, ele compôs seu famoso Sermão aos pássaros. Texto idílico, louvor das criaturas, ele pode ser entendido como uma contraposição ao antimaterialismo herético. A novidade franciscana em relação ao catarismo foi, apesar de tangenciando a heresia, ter se mantido no seio da Igreja — salvo sua ala mais radical, a dos chamados franciscanos Espirituais, dos quais os primeiros queimados, em 1318, em Marselha, tinham vivido em plena zona de influência cátara.

Enfim, o catarismo tinha quase todas as características de qualquer sociedade utópica, salvo duas - ordem e prosperidade. Com efeito, ele recusava a ideia de prosperidade devido ao seu arraigado antimaterialismo, o que tornou mais intensa a busca de pureza, igualdade, fraternidade, justiça e paz. A ordem terrena não era uma de suas metas porque implica o estabelecimento de uma hierarquia e o uso da autoridade e da força, o que os cátaros repudiavam devido à sua

${ }^{101}$ SACCONI, Raniero, Summa de catharis et leonistis pauperibus de Lugduno, op. cit., p. 50, linhas 1819 (a informação do autor sobre sua condição anterior de cátaro está à p. 45, linha 19). As estimativas modernas são discordantes: GUIRAUD, Jean. Histoire de l'Inquisition, au Moyen Age, op. cit., pensa que na metade sul da França os cátaros constituíram-se na "maior parte da populaçáo" (v. I, p. 277 e 357), enquanto BIGET, Jean-Louis. Hérésie et inquisition dans le midi de la France. Paris: Picard, 2007, calcula que eles jamais ultrapassaram ali 5\% da população total e 10\% da urbana (p. 130 e 216-217).

${ }^{102}$ A primeira menção nesse sentido, que conheçamos, está nos Annales Florentini. In: Pertz, Georg H. (Ed.). Monumenta Germaniae Historica. Berlim/Stuttgart/Hanover: Weidmann/Hiersemann/Hahniani, 1866, p. 224. v. 19. linha 8.

${ }^{103}$ SÃO BOAVENTURA. Legenda Maior, IV, 1. In: Fontes franciscanas I. S. Francisco de Assis. Braga: Editorial Franciscana, 2005, p. 596. 
concepção anarquista da sociedade. ${ }^{104}$ Para concretizá-la, contudo, seria preciso primeiro mudar o homem para depois mudar a sociedade, da mesma forma que pensaria mais tarde Thomas More $^{105}$ - e nisso residia o caráter propriamente utópico, inatingível, das duas propostas.

Enquanto esperavam o momento de regressar à sua pátria celeste, os homens que se reformaram “imaginavam uma outra terra, nova e invisível”. ${ }^{106} \mathrm{Na}$ crença popular cátara, após a morte corporal ninguém vai imediatamente ao Inferno ou ao Paraíso, e sim a um "lugar de repouso" geralmente identificado com o Paraíso terrestre. ${ }^{107}$ Como aquela terra renovada é onde "de acordo com alguns o bom Cristo tinha nascido e sido crucificado", ${ }^{108}$ ela parece corresponder à visão idealizada que se tinha nos séculos XII-XIII da Jerusalém terrestre, que é "quasi alter Paradisus deliciarum" no dizer de um cronista. ${ }^{109}$ De fato, a terram novam foi preparada por Deus, daí sua excelência, suas pedras serem safiras, seus montes de ouro, daí ser morada da justiça e da Árvore da Vida, conforme descreve um tratado do começo do século XIII. ${ }^{110}$ Dito de outra forma, a terra "nova e invisível" dos cátaros equivalia em certa medida ao conceito de utopia forjado por More três séculos mais tarde.

\section{Referências bibliográficas}

\section{Fontes primárias}

ACTA inquisitionis Carcassonensis contra Albigenses ann. 1308 et 1309. In: PALES-GOBILLIARD, Annette (Ed./Trad.). L'inquisiteur Geoffrey d'Ablis et les cathares du comté de Foix (1308-1309). Paris: CNRS, 1984.

AMBRÓSIO, Santo. Expositio Psalmi CXVIII. Tradução de Luigi Franco Pizzolato. In: PETSCHENIG, Michael (Ed.). Commento al Salmo CXVIII. Milāo/Roma: Biblioteca Ambrosiana/ Città Nuova, 1987. (Operaomnia di Sant'Ambrogio, v. 10)

ANDRÉ FLORENTINO. Summa contra hereticos. In: ROTTENWÖHRER, Gerhard (Ed.). Monumenta Germaniae Historica. Quellen zur Geistesgeschichte des Mittelalters, v. 23. Berlim/ Stuttgart/Hanover: Weidmann/Hiersemann/Hahniani, 2008.

${ }^{104}$ GUIRAUD, Jean. Histoire de l'Inquisition, au Moyen Age, op. cit., v. I, p. 99. Já se viu no catarismo "uma espécie de cristianismo 'de extrema-esquerda' se se quiser recorrer a esta qualificação com certeza completamente anacrônica”: LADURIE. Introduction. In: BRENON, Anne; DIEULAFAIT, Christine (Orgs.). Autour de Montaillou. Un village occitan. Castelnaud la Chapelle: L'Hydre, 2001. p. 14.

${ }^{105}$ L'Utopiae, I, p. 62 (433), linhas 23-25.

${ }^{106}$ PEDRO DES VAUX-DE-CERNAY. Hystoria Albigensis, op. cit., I, 11, p. 11. Também se refere à "nova terra" a Manifestatio heresis albigensium, p. 270, linha 81.

${ }^{107}$ Herrores heretiquorum, op. cit., p. 213; Fonds Doat, v. 25, fol. 196v-201v; Registre, v. I, p. 139; v. II, p. 463, 483, 484, 491, 498, 509 e 512. A ideia de um Paraíso terrestre como local de espera parece ter sido inspirada ao catarismo, como tantas outras coisas, por ORIGENES. Traité des principes. Edição e traduçáo de Henri Crouzel e Manlio Simonetti. Paris: Cerf, 1978. (Sources Crétienes, v. 252), II, 11, 6, p. 408.

${ }^{108}$ PEDRO DES VAUX-DE-CERNAY, Hystoria Albigensis, op. cit., I, 11, p. 11.

${ }^{109}$ ROBERTO, O MONGE. Historia hierosolymitana. In: Bongars Jacques (Ed.). Recueil des historiens des Croisades. Paris: Imprimerie Impériale, 1866, v. 3, p. 729a.

${ }^{110}$ Une somme anti-cathare, le Liber contra Manicheos de Durand de Huesca. Edição de Christine Thouzellier. Louvain: Spicilegium sacrum Lovaniense, 1964, p. 106. 
ANNALES Aquenses. In: PERTZ, Georg H. (Ed.). Monumenta Germaniae Historica. Berlim/Stuttgart/Hanover: Weidmann/Hiersemann/Hahniani, 1859, p. 684-687. v. 16. Disponível em: <http://www.dmgh.de/de/fs 1/object/display/bsb00000943_00697. html? sortIndex=010\%3A050\%3A0016\%3A010\%3A00\%3A00>.

ANNALES Florentini. In: PERTZ, Georg H. (Ed.). Monumenta Germaniae Historica. Berlim/Stuttgart/Hanover: Weidmann/Hiersemann/Hahniani, 1866, p. 223-224. v. 19. Disponível em: <http://www.dmgh.de/de/fs 1/object/display/bsb00000860_00261. html?sortIndex=010\%3A050\%3A0019\%3A010\%3A00\%3A00>.

ANSELMO DE ALEXANDRIA. Tractatus de hereticis. In: DONDAINE, Antoine (Ed.). La hiérarchie cathare en Italie. Archivum Fratrum Praedicatorum, Roma, v. 20, p. 234-324, 1950.

BERNARDO, São. Sermones super Cantica canticorum. Edição de Jean Leclerq, Charles H. Talbot e Henri M. Rochais. Roma: Editiones Cistercienses, 1958 (S. Bernardi opera, v. II).

BERNARDO GUI. Manuel de l'inquisiteur. Tradução e edição de Guillaume Mollat. Paris: Les Belles Lettres, 2006 (Les Classiques de l'Histoire de France au Moyen Âge, v. 44).

Biblia. Lyon, Bibliothèque Municipale, ms. P.A. 36. Biblia Sacra iuxta Vulgatam Clementinam. 7. ed. Edição de Alberto Colunga e Laurentio Turrado. Madri: BAC, 1985.

SÃO BOAVENTURA. Legenda Maior, IV, 1. In: Fontes franciscanas I. S. Francisco de Assis. Braga: Editorial Franciscana, 2005.

BONACURSO DE MILÃO. Manifestatio heresis catharorum. In: MIGNE, Jacques-Paul (Ed.) Patrologia Cursus Completus. Series Latina. [1844-1864]. Turnhout: Brepols, 1855. v. 204, col. 775792. Disponível em: <https://archive.org/details/patrologiaecurs97unkngoog>.

CESÁRIO DE HEISTERBACH. Dialogus miraculorum. Edição de Joseph Strange. Colônia: J. M. Heberle, 1851. 2v.

CHRONICA regia Coloniensis. In: WAITZ, Georg (Ed.). Monumenta Germaniae Historica. Rerum germanicarum in usum scholarum, v. 18. Berlim/Stuttgart/Hanover: Weidmann/Hiersemann/ Hahniani, 1880. Disponível em: <http://www.dmgh.de/de/fs1/object/display/bsb00000 768 _ meta:titlePage.html?sortIndex=010:070:0018:010:00:00>.

CIPRIANO. Liber de unitate ecclesiae. In: MIGNE, Jacques-Paul (Ed.). Patrologia Cursus Completus. Series Latina. [1844-1864]. Turnhout: Brepols, 1844. v. 4, col. 493-520. Disponível em: <https:// archive.org/details/patrologiaecursu04hammuoft>.

CONCILIOS visigóticos e hispano-romanos. Edição e tradução de José Vives. Barcelona/Madri: CSIC/Instituto Enrique Flórez, 1963.

CONFESSIONES de V libro Lauraguesii Fratris Bernardo de Cautio transcripto. Toulouse: Bibliothèque Municipale, ms. 609. Transcrição disponível em: <http://jean.duvernoy.free.fr/text/listetexte.htm>.

EGBERTO DE SCHÖNAU. Sermones contra catharos. In: MIGNE, Jacques-Paul (Ed.) Patrologia Cursus Completus. Series Latina. [1844-1864]. Turnhout: Brepols, 1855. v. 195, col. 11-98. Disponível em: <https://archive.org/details/patrologiaecurs68unkngoog>.

ERMENGALDO DE BÉZIERS. Opusculum contra haereticos. In: MIGNE, Jacques-Paul (Ed.). Patrologia Cursus Completus. Series Latina. [1844-1864]. Turnhout: Brepols, 1985-1995. v. 204, col. 
1235-1272. Disponível em: <https://archive.org/details/patrologiaecurs97unkngoog>.

EUSÉBIO DE CESAREIA. Histoire ecclésiastique. Edição e tradução de Gustave Bardy. Paris: Cerf, 1955. (Sources Chrétiennes, v. 41)

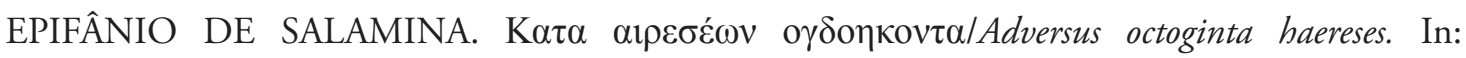
MIGNE, Jacques-Paul (Ed.). Patrologia Cursus Completus. Series Graeca. Turnhout: Brepols, 1984-1991. v. 41, col. 173-1199. Disponível em: <https://books.google.fr/books?id=CZtkTuu ZxkgC\&hl=fr\&pg=PP1\#v=onepage\&q\&f=false $>$.

EVERVINO DE STEINFELD. Epistola ad S. Bernardum. In: MIGNE, Jacques-Paul (Ed). Patrologia Cursus Completus. Series Latina [1844-1864]. Turnhout: Brepols, 1985-1995. v. 182, col. 676-680. Disponível em: <https://archive.org/details/ patrologiaecurs62unkngoog>. Fonds Jean Doat, Paris, Bibliothèque Nationale, ms. nouv. acq. fr. 22765, 258 v.

GREGÓRIO DE FANO. Disputatio inter catholicum et paterinum hereticum. Edição de Ilarino da Milano. Aevum, Milão, v. 14, p. 85-140, 1940.

GUILHERME DE PUYLAURENS. Chronica/Chronique, 1145-1275. Tradução e edição de Jean Duvernoy. Toulouse: Le Pérégrinateur, 1996. DE heresi catharorum in Lombardia. In: DONDAINE, Antoine (Ed.). Hiérarchie cathare en Italie. Archivum Fratrum Praedicatorum, Roma, v. 19, p. 280-312, 1949.

HERRORES heretiquorum. In: MOLINIER, Charles (Ed.). Un texte de Muratori concernant les sectes cathares: sa provenance réelle et sa valeur. Annales du Midi, Toulouse, v. 22, p. 180-220, 1910. Disponível em: <http://www.persee.fr/doc/anami_0003-4398_1890_num_2_6_2989>.

IRENEU. Contra as heresias. In: DOUTRELEAU, Louis; ROUSSEAU, Adelin (Ed./Trad.). Contre les hérésies. Paris: Cerf, 1979. (Sources Chrétiennes, v. 264).

ISIDORO DE SEVILHA. Etimologías. Edição de Wallace M. Lindsay. Tradução de José Oroz Reta e Marco Casquero. Madri: BAC, 1982. 2v.

LE Nouveau Testament traduit au XIII siècle en langue provençale suivi d'un rituel Cathare. Edição de Léon Clédat. Paris: Leroux, 1887 (Bibliothèque de la Faculté des Lettres de Lyon, v. 4). Disponível em: <http://gallica.bnf.fr/ark:/12148/bpt6k91152k>.

LE livre secret des cathares. Interrogatio Iohannis, apocryphe d'origine bogomile. Edição e tradução de Edina Bozóki. Paris: Beauchesne, 1980.

LE livre des sentences de l'inquisiteur Bernard Gui, 1308-1323. Tradução e edição de Annette PalesGobilliard. Paris: CNRS, 2002.

LE registre d'inquisition de Jacques Fournier, évêque de Pamiers (1318-1325). Edição de Jean Duvernoy. Toulouse: Privat, 1965. 3v.

LIBER miraculorum Sancte Fidis. Edição de Luca Robertini. Spoleto/Florença: CISSAM/ SISMEL, 1994.

LIVRE des deux principes. In: THOUZELLIER, Christine. Livre des deux principes. Paris: Cerf, 1973. (Sources Crétienes, v. 198).

LOS capitulos de Rabbi Eliezer. Edição de David Luria. Tradução de Miguel Pérez Fernández. Valência: Institución San Jerónimo para la investigación bíblica, 1984. 
LUCAS DE TUY. De altera vita. In: REY, Emma Falque. Corpus Christianorum Continuatio Medievalis. Turnhout: Brepols, 2009, v. 74A.

MANIFESTATIO haeresis albigensium et lugdunensium. In: DONDAINE, Antoine (Ed.). Durand de Huesca et la politique anticathare. Archivum Fratrum Praedicatorum, Roma, 29, p. 268$271,1959$.

MATEUS PARIS. Chronica majora. Edição de Henry R. Luard. Londres: Longman, 1876 (Rerum Britannicarum Medii Aevi Scriptores, v. 57-V).

MESLIER, Jean. Mémoires des pensées et sentiments [1729]. Edição de Roland Desné. Paris: Anthropos, 1974 (CEuvres complètes, v. 1).

MONETA DE CREMONA. Adversus catharos et valdenses. Edição de Tommaso Agostino Ricchini. Roma: N. e M. Palearini, 1743. Disponível em: <https://archive.org/details/ venerabilispatri00mone>.

MORE, Thomas. L'Utopie. Edição e tradução de André Prévost. Paris: Mame, 1978.

NARRATIVE and legislative texts from early Cîteaux. Edição de Chrysogonus Waddel. Cîteaux: Commentarii cistercienses, 1999 (Studia et Documenta, v. IX).

ORÍGENES. Traité des principes. Edição e tradução de Henri Crouzel e Manlio Simonetti. Paris: Cerf, 1978. (Sources Crétienes, v. 252)

PEDRO DES VAUX-DE-CERNAY. Hystoria Albigensis. Edição de Pascal Guébin e Ernest Lyon. Paris: Honoré Champion, 1926.

PLATÃO. Platon, auvres complètes. Organização de Luc Brisson. Paris: Flammarion, 2009.

PREPOSTINO DE CREMONA. Svmma contra haereticos. Edição de Joseph Garvin e James Corbett. Notre Dame (Indiana): University of Notre Dame Press, 1958.

RALPH DE COGGESHALL. Chronicon anglicanum. Edição de Joseph Stevenson. Londres: Longman, 1875 (Rerum Britannicarum Medii Aevi Scriptores, v. 66).

RITUAL Cátaro. In: THOUZELLIER, Christine (Ed./Trad.). Rituel cathare. Paris: Cerf, 1977. (Sources Crétienes, v. 236)

ROBERTO, O MONGE. Historia hierosolymitana. In: BONGARS Jacques (Ed.). Recueil des historiens des Croisades. Paris: Imprimerie Impériale, 1866, p. 717-882. v. 3. Disponível em: <http:// gallica.bnf.fr/ark:/12148/bpt6k51573t/f790.image>.

SACCONI, Raniero. Summa de catharis et leonistis pauperibus de Lugduno. Edição de François Sanjek. Archivum Fratrum Praedicatorum, Roma, v. 44, p. 31-60, 1974.

SALVO BURCI. Liber supra stella. Edição de Ilarino da Milano. Aevum, Milão, v. 19, p. 307-341, 1945.

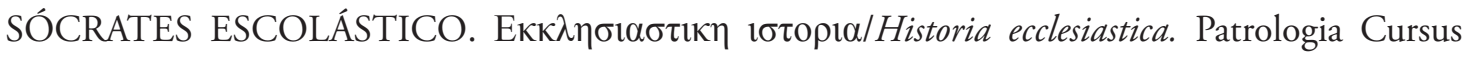
Completus. Series Graeca. Edição de Jacques-Paul Migne e Henri de Valois [1857-1886]. Turnhout: Brepols, 1984-1991 v. 67, col. 29-842. Disponível em: <https://books.google.fr/ books?id=ZuhUflczEzoC\&hl=fr \&pg=PA10\#v=onepage\&q\&f=false>.

TERTULIANO. De praescriptione haereticorum. Edição de François Refoulé et alii. Corpus Christianorum Series Latina. Turnhout: Brepols, 1954. v. 1, p. 185-224. 
TRACTATUS manicheorum. In: THOUZELLIER, Christine (Ed.). Un traité cathare inédit du début du XIII siècle d'après le Liber Contra Manicheos de Durand de Huesca. Louvain: Université de Louvain, 1961 (Bibliothèque de la Revue Ecclésiastique, v. 37).

UN recueil cathare: le manuscrit A.6.10 de la Collection vaudoise de Dublin. In: VENCKELEER, Théo (Ed.). Revue belge de philologie et d'histoire, Bruxelas, v. 38, p. 815-834, 1960.

UNE somme anti-cathare, le Liber contra Manicheos de Durand de Huesca. Edição de Christine Thouzellier. Louvain: Spicilegium sacrum Lovaniense, 1964 (Études et documents, v. 32).

\section{Fontes secundárias}

BENDA, Julien. La trahison des clercs [1927]. Paris: Grasset, 1995.

BIGET, Jean-Louis. Hérésie et inquisition dans le midi de la France. Paris: Picard, 2007 (Les médiévistes français, v. 8).

BLADEL, Frans Van. Penser l'utopie. Collectanea Cisterciensia. Revue de spiritualité monastique, Orval (Bélgica), v. 65, p. 48-60, 2003.

BRENON, Anne; DIEUlAFAIT, Christine (Orgs.). Autour de Montaillou. Un village occitan. Castelnaud la Chapelle: L'Hydre, 2001.

Cathares en Languedoc. Toulouse: Privat, 1968 (Cahiers de Fanjeaux, v. 3).

Le Credo, la Morale et l'Inquisition. Toulouse: Privat, 1971 (Cahiers de Fanjeaux, v. 6).

DONDAINE, Antoine. Les actes du concile albigeois de Saint-Félix de Caraman. In: Miscellanea Giovanni Mercati. Vaticano: Biblioteca Apostolica, 1944, p. 324-355. v. V.

DOUAIS, Mari-Jean Célestin. Les manuscrits du château de Merville. Annales du Midi. Toulouse, v. 2, n. 6, p. 170-208, 1890. Disponível em: <http://www.persee.fr/doc/anami_0003-4398_1890_num_2_6_2989>.

DRÖES, Freda. De Katharen grens van een cultuur?. Amsterdâ: Katholieke Theologische Hogeschool, 1982. DUVERNOY, Jean. La religion des cathares [1976]. Toulouse: Privat, 1996.

Effacement du catharisme (XIII-XIV s.)?. Toulouse: Privat, 1985 (Cahiers de Fanjeaux, v. 20).

FRANCO JÚNIOR, Hilário. Catolicismo e catarismo, um choque de mitologias. Cadernos de História, Belo Horizonte, v. 12, p. 9-28, 2010. Disponível em: <http://periodicos.pucminas.br/ index.php/cadernoshistoria/article/view/P.2237-8871.2010v11 n14p9>.

. Nos confins do mundo, na vizinhança do Paraíso: a utopia Monástica. Graphos, João Pessoa, v. 19, n. 3, 2017, p. 9-32. Disponível em: <http://periodicos.ufpb.br/ojs2/index.php/graphos/ article/view/37771/19074>.

A utopia que não está no fim da viagem: a peregrinação. Morus, Campinas, v. 7, p. 155-177, 2010. Disponível em: <http://revistamorus.tempsite.ws/index.php/morus/issue/view/20/showToc>.

GRECO, Alessandra. Mitologia catara. Il favoloso mondo delle origini. Spoleto: CISSAM, 2000. p. 224.

GUIRAUD, Jean. Histoire de l'Inquisition au Moyen Age. Paris: Auguste Picard, 1938. 2v.

JIMÉNEZ-SANCHEZ, Pilar. Les catharismes. Modèles dissidents du christianisme médiéval (XII ${ }^{\text {e }}$ XIII' siècles). Rennes: Presses Universitaires de Rennes, 2008. 
LADURIE, Emmanuel Le Roy. Montaillou, povoado occitânico, 1294-1324 [1975]. São Paulo: Companhia das Letras, 1997.

MILES, Leland. The Platonic source of Utopia’s minimum religion. Renaissance News, Chicago, v. 9, n. 2, p. 83-90, 1956.

MOLNAR, Thomas. Utopia, the perennial heresy. Nova York: Sheed and Ward, 1967.

NELLI, René. La vie quotidienne des cathares du Languedoc au XIII siècle. Paris: Hachette, 1969.

PEGG, Mark G. A Most Holy War. The Albigensian Crusade and the battle for Christendom. Oxford: Oxford University Press, 2008.

QUARTA, Cosimo. Livelli del pensiero utopico: antropologia, storia, letteratura. Morus, Campinas, v. 6, p. 232-239, 2009. Disponível em: <www.revistamorus.com.br/index.php/morus/article/viewFile/.../67>.

STOCK, Brian. The Implications of Literacy: Written Language and Models of Interpretation in The Eleventh and Twelfth Centuries. Princeton: Princeton University Press, 1983.

VERDON, Laure. La femme en Roussillon aux XII ${ }^{e}$ et XIII ${ }^{e}$ siècles. Statut juridique et économique. Annales du Midi, Toulouse, v. 111, n. 227, p. 293-309, 1999. Disponível em: <http://www.persee. fr/doc/anami_0003-4398_1999_num_111_227_2633>.

\section{Abreviaçóes}

CCCM - Corpus Christianorum Continuatio Medievalis. Turnhout: Brepols, 1967ss, 344 v. (em curso). CCSL - Corpus Christianorum Series Latina. Turnhout: Brepols, 1954ss, 212 v. (em curso).

MGH - Monumenta Germaniae Historica (subdividida em cinco séries e várias subséries). Berlim/ Stuttgart/Hanover: Weidmann/Hiersemann/Hahniani, 1826ss, 300 v. (em curso).

PG - Patrologia Cursus Completus. Series Graeca. MIGNE, Jacques-Paul (Ed.) [1857-1886]. Turnhout: Brepols, 1984-1991. 162v.

PL-Patrologia Cursus Completus. Series Latina. MIGNE, Jacques-Paul (Ed.) [1844-1864]. Turnhout: Brepols, 1985-1995. 221v.

Registre - Le registre d'inquisition de Jacques Fournier, évêque de Pamiers (1318-1325). Duvernoy, Jean (Ed.). Toulouse: Privat, 1965. 3v.

SC - Sources chrétiennes. Paris: Cerf, 1943ss, 584 v. (em curso).

\section{Como citar:}

FRANCO JÚNIOR, Hilário. Catarismo, uma manifestação utópica medieval. Topoi. Revista de História, Rio de Janeiro, v. 19, n. 38, p. 6-34, mai./ago. 2018. Disponível em: $<$ www.revistatopoi.org $>$. 